
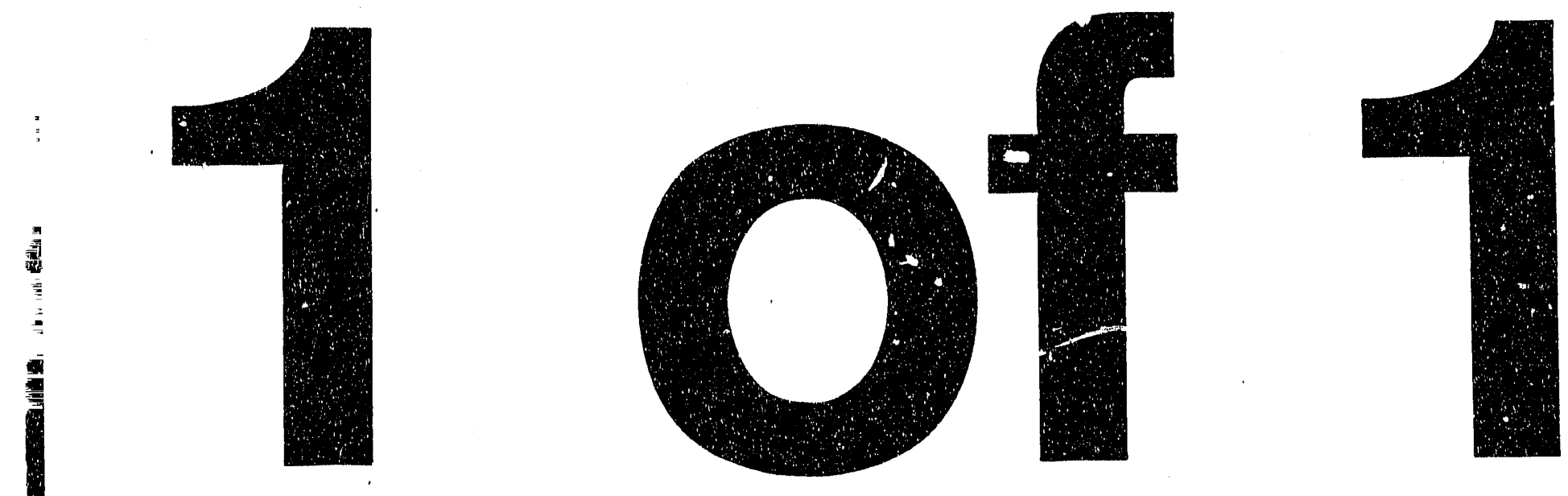


\section{Approach for Tank Safety Characterization of Hanford Site Waste}

Prepared for the U.S. Department of Energy Office of Environmental Restoration and Waste Management

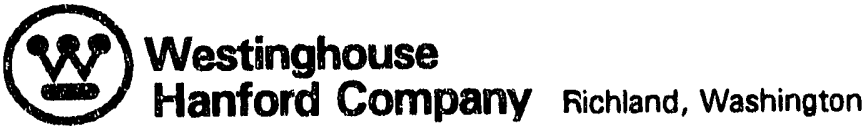

Hanford Operations and Engineering Contractor for the U.S. Department of Energy under Contract DE-AC06-87RL10930 
IEEAL DHSCLAMER

This report was propared as an account of work sponsored by an agenoy of the United States Government. Noither the United Statos Government nor any agenoy thereof, nor any of their employses, nor any of their contractors, eubcontractore or their employees, makes any werranty, exprese or irnplied, or asoumes any loged liability or responsibility for the accuracy, completeness, or any third party's use or the results of such use of any information, apparatus, product, or process disclosed, or represents thet its use would not infringo privetely owned rights. Reforence heroin to any specific commorcial product, process, or service by trade neme, tredemark, manufacturer, or otherwise, does not nocessarily constitute or imply its endorsement, recominendation, or fovoring by the United States Government or any agency thereof or its contrectors or suboontractors. The views and opinions of euthors expressed herein do not nocessarily stato or reflect those of the United States Government of any agenoy thereof.

This report has been reproduced from the best available copy. Aveilable in paper copy and microficho.

Available to the U.S. Dopartment of Energy and its cuntractors from

Office of Scientific and Tochnicel Information

P.O. Box 62

Oak Ridge, TN 37831

(615) 576-8401

Aveilable to the public from the U.S. Department of Commerce Netional Tochnical Information Sorvico

5285 Port Roy Roed

Springfiold, VA 22161

(703) $487-4650$

Printed in the Unitad Stotion of America

DISCLM-1.CHP (1-91) 


\section{Approach for Tank Safety Characterization of Hanford Site Waste}
J. E. Meacham
H. Babad
R. J. Cash
G. T. Dukelow
S. J. Eberlein
D. W. Hamilion
G. D. Johnson
J. W. Osborne
M. A. Payne
D. J. Sherwood
D. A. Turner

Westinghouse Hanford Company

J. L. Huckaby

Pacific Northwest Laboratory

Date Published

March 1995

Prepared for the U.S. Department of Energy Office of Environmental Restoration and Waste Management

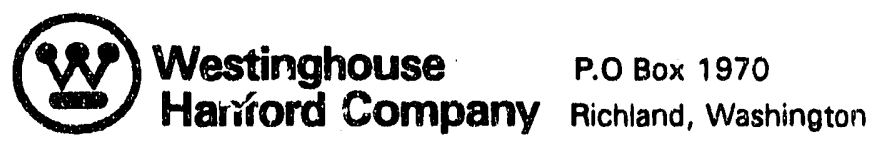

Henford Operations and Engineering Contractor for the U.S. Depertment of Energy under Contract DE-AC06-87RL10930 


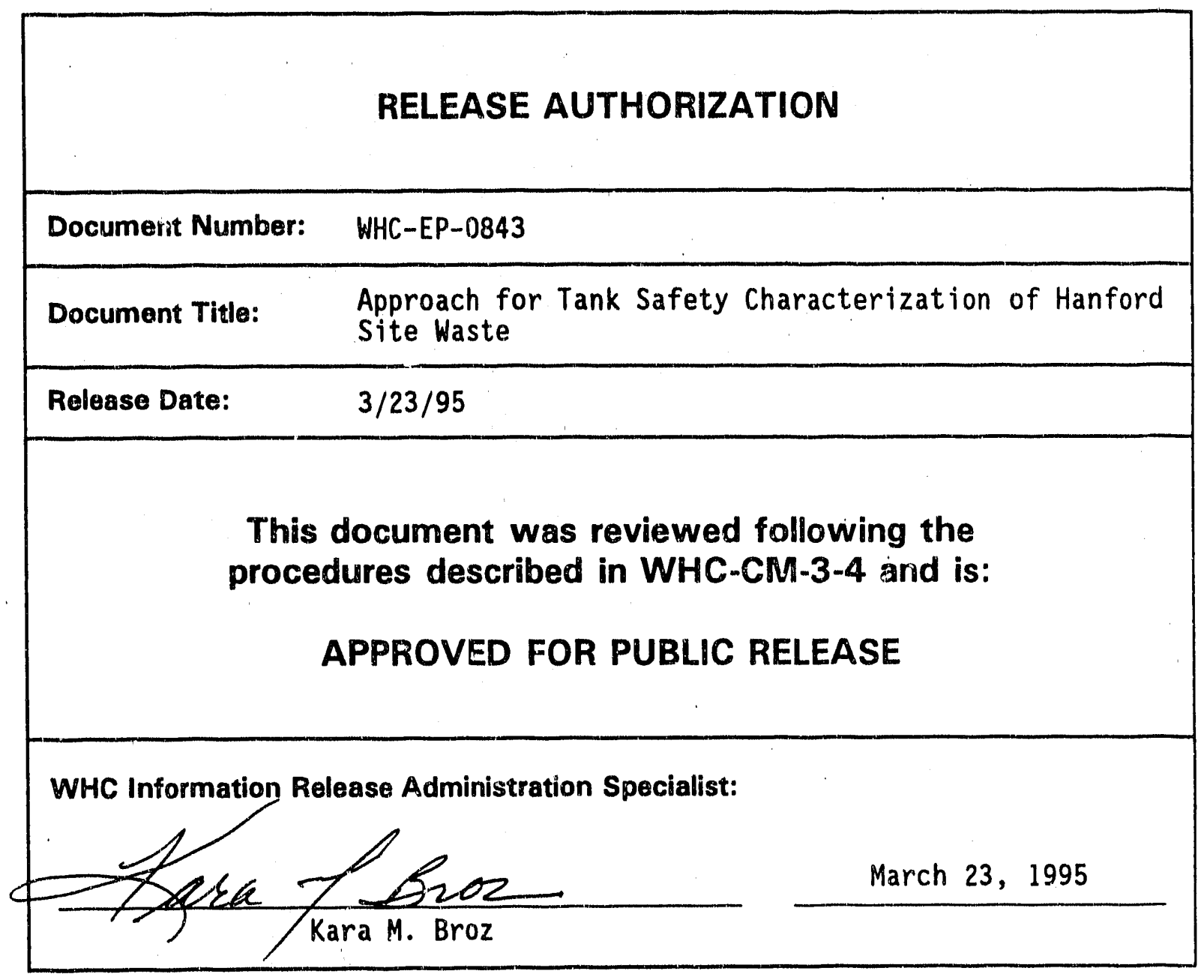

A-6009-400 (07/94) WEF256 


\title{
APPROACH FOR TANK SAFETY CHARACTERIZATION \\ OF HANFORD SITE WASTE
}

\begin{abstract}
The overall approach and associated technical basis for characterizing Hanford Site waste to help identify and resolve Waste Tank Safety Program safety issues has been summarized. The safety issues include flammable gas, noxious vapors, organic solvents, condensed-phase exothermic reactions (ferrocyanide and organic complexants), criticality, high heat, and safety screening.

For the safery issues involving chemical reactions (i.e., flammable gas, organic solvents, ferrocyanide, and organic complexants), the approach to safety characterization is based on the fact that rapid exothermic reactions cannot occur if either fuel, oxidizer, or temperature (initiators) is not sufficient or controlled. Because specific limits of fuel, oxidizer, and temperature (initiators) must be satisfied for a chemical reaction to occur, waste can be stored safely if the conditions for reaction are not met. Therefore, the characterization approach is to confirm that one of the conditions of fuel, oxidizer, or teriperature (initiators) is not sufficient or that at least one condition is controlled.

The approach to characterization has been influenced by the progress made since mid-1993: (1) completion of safety analyses on ferrocyanide, criticality, organic solvent in tank 241-C-103, and sludge dryout: (2) successful mitigation of tank 241-SY-101;

(3) demonstration of waste aging in laboratory experiments and from waste sampling; and

(4) increased understanding of the information that can be obtained from headspace sampling. All these accomplishments have helped refine the direction of safety characterization.
\end{abstract}

Sources of data for safety characterization include: (1) reviews of process flowsheets, waste transfer records, monitoring data, and historical sample data; (2) visual inspections of the waste; (3) interrogation of the tank headspace using standard hydrogen monitors and vapor sampling; (4) temperature and moisture monitoring; and (5) analyses of waste samples obtained from liquid grab sampling, surface auger sampling, and full-depth core sampling. Headspace vapor sampling is being used to confirm that flammable gas does not accumulate in the single-shell tanks, and to determine whether organic solvents are present. The headspaces of tanks that may contain significant quantities of flammable gas will be monitored continuously using standard hydrogen monitors.

For the noxious vapors safety issue, characterization will consist of headspace vapor sampling of most of the Hanford Site waste tanks. Sampling specifically for criticality is not required to confirm interim safe storage; however, analyses for fissile material will be conducted as waste samples are obtained for other reasons. High-heat tanks will be identified through temperature monitoring coupled with thermal analyses. 
This page intentionally left blank. 


\section{TABLE OF CONTENTS}

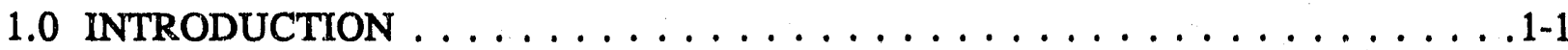

1.1 OBJECTIVE AND SCOPE OF DOCUMENT $\ldots \ldots \ldots \ldots \ldots \ldots \ldots$

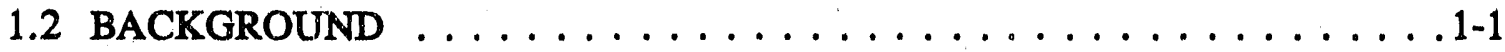

2.0 NECESSARY CONDITIONS FOR EXOTHERMIC CHEMICAL REACTIONS _ . 2-1

3.0 TECHNICAL BASIS FOR SAFETY CHARAC TERIZATION $\ldots \ldots \ldots$. . . . . 3-1

3.1. HISTORICAL INFORMATION . . . . . . . . . . . . . . . . . . 3-1

3.2 MODELS GUIDING SAFETY CHARACTERIZATION $\ldots \ldots \ldots \ldots \ldots$. . . . . .

3.3 FLAMMABLE GASES AND NOXIOUS VAPORS . . . . . . . . . . . . . 3-2

3.3.1 Flammable Gas Hazard . . . . . . . . . . . . . . . . 3-2 . . . . . . . . . . . .

3.3 .2 Noxious Vapor Hazard . . . . . . . . . . . . . . . . 3-4

3.4 ORGANIC SOLVENTS . . . . . . . . . . . . . . . . . 3-5

3.4.1 Organic Solvent Hazard . . . . . . . . . . . . . . . 3-5

3.4.2 Relationship Between Organic Solvent and Organic Vapor . . . . . 3-5

3.4.3 Entrained Organic Solvent . . . . . . . . . . . . . . . . . 3-6

3.5 FUEL-NITRATE (CONDENSED-PHASE) REACTIONS . . . . . . . . . 3-6

3.5 .1 Safety Criteria . . . . . . . . . . . . . . . . . . . . . . . . . .

3.5 .2 Heat Loads . . . . . . . . . . . . . . . . . . . . . . . . . . . . . . . . . . .

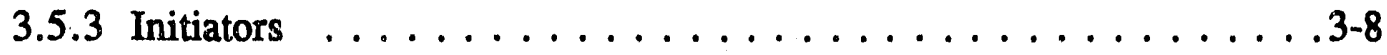

3.5 .4 Moisture in Waste Sludges . . . . . . . . . . . . . . . 3-9 . . . . . . . . . . .

3.5.5 Moisture in Saltcake Waste . . . . . . . . . . . . . . 3-10

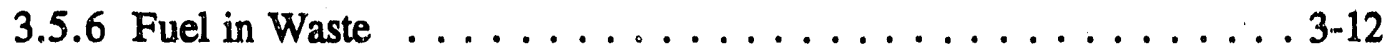

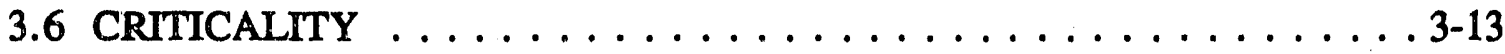

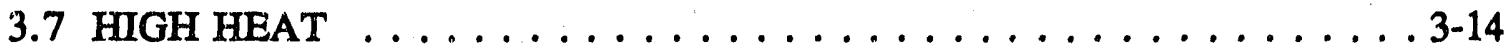

3.8 AMOUNT OF CHARACTERIZATION REQUIRED . . . . . . . . . . . 3-14

4.0 APPROACH TO SAFETY SCREENING $\ldots \ldots \ldots \ldots \ldots \ldots \ldots \ldots \ldots$

4.1 SAFETY SCREENING LOGIC . . . . . . . . . . . . . . . . . 4-1

4.2 DEFICIENCIES IN THE PREVIOUS APPROACH $\ldots \ldots \ldots \ldots \ldots \ldots . . . .4-4$

5.0 RESOLUTION OF EACH SAFETY ISSUE $\ldots \ldots \ldots \ldots \ldots \ldots \ldots$

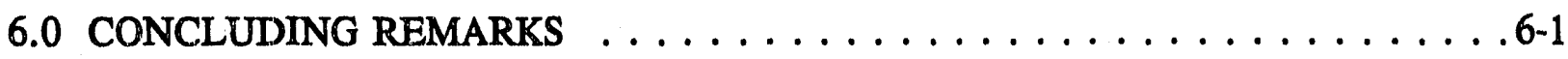

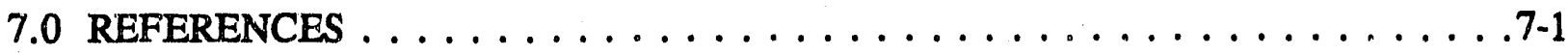

APPENDIXES

A TANKS CURRENTLY ON THE WATCH LIST $\ldots \ldots \ldots \ldots \ldots \ldots \ldots$. . . . . . . .

B HOMOGENEITY IN THE HEADSPACE $\ldots \ldots \ldots \ldots \ldots \ldots \ldots \ldots \ldots$. . . . . . . .

C DETECTION OF A SEPARABLE ORGANIC PHASE $\ldots \ldots \ldots \ldots \ldots \ldots . . .$.

D PRELIMINARY NEAR-SURFACE CALCULATIONS $\ldots \ldots \ldots \ldots \ldots \ldots$. . . . 


\section{LIST OF FIGURES}

4-1 Safety Screening $\operatorname{Logic} \ldots \ldots \ldots \ldots \ldots \ldots \ldots \ldots \ldots \ldots \ldots$

\section{LIST OF TABLES}

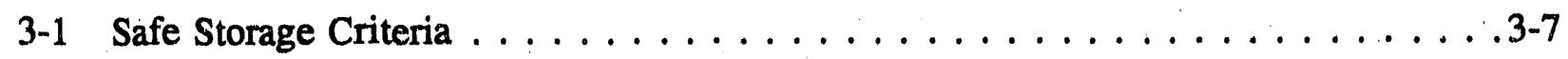

3-2 Summary of Operations Evaluation $\ldots \ldots \ldots \ldots \ldots \ldots \ldots \ldots$

\section{LIST OF TERMS}

CES Consensus Exposure Standard

DST Double-Shell Tank

EMI Electromagnetic Induction

LFL Lower Flammability Limit

NPH Normal Paraffin Hydrocarbon

SST Single-Shell Tank 


\section{APPROACH FOR TANK SAFETY CHARACTERUZATION OF HANFORD SITE WASTE}

\subsection{INTRODUCTION}

\subsection{OBJECTIVE AND SCOPE OF DOCUMENT}

This document summarizes the overall approach and associated technical basis for characterizing Hanford Site waste to identify and resolve safety issues (i.e., characterization for determining whether the waste is stored within established safety envelopes). This is a summary document; the full technical bases are provided by the safety analyses cited throughout the document. Details on the number and frequency of samples, data quality requirements, and confidence levels are not presented in this document, but are covered in the individual data quality objective documents for the safety issues.

The scope of this document is limited to activities within the Waste Tank Safety Program. Specifically, the characterization associated with flammable gas, noxious vapors, organic solvents, condensed-phase exothermic reactions (ferrocyanide and orgaric complexants), criticality, high heat, and safety screening are discussed. Other problems, such as detection and prevention of leaks to the soil, are not included.

\subsection{BACKGROUND}

One hundred and seventy-seven underground storage tanks at the Hanford Site store highlevel radioactive liquid waste in quantities that generally exceed a few hundred thousand liters, with radioisotope concentrations of about one-fourth curie per liter. The 28 newer double-shell tanks (DSTs) are typically filled to near 4.4-million-liter capacities, while the older single-shell tanks (SSTs) are often only partially filled.

Safety issues associated with Hanford Site waste tanks arose because of inadequate safety analyses and high levels of unc rtainty over the exposure of workers to noxious vapors, and the release of radioactivity resulting from exothermic chemical reactions, a criticaity, or a tank structural failure from high heat. Much work has been completed within the Waste Tank Safety Program to establish safety envelopes and reduce the uncert " 11y. The approach to characterization has been influenced by the progress made since mid-1993.

Safety analyses on tank 241-C-103 (which contains an organic solvent pool), ferrocyanide, and criticality have focused the characterization requirements for these issues (zee Sections 3.4, 3.5, and 3.6, respectively). Experiments and analyses on fuel-nitrate reactions, waste aging, and sludge moisture retention have helped define the effect of fuel, moisture, and temperature (initiators) on interim safe storage. Installation of the mixer pump in tanik 241-SY-101 mitigated the one tank known to release flammable gas at concentrations above 
the lower flammability limit (see Section 3.3.1), and an enhanced vapor sampling capability will screen for additional safety issues for the Hanford Site tanks (see Section 3.3).

The early focus of waste characterization in the Waste Tank Safety Program involved heavy reliance on historical information and monitoring data to identify tanks at risk. This approach proved to be appropriate for identifying tanks with potential flammable gas, ferrocyanide, criticality, high-heat, and organic complexant safety issues. However, examinations of historical information were only partially successful in identifying organic solvent and noxious vapor tanks. Further characterization will be necessary to produce additional factual safety analyses. 


\subsection{NECESSARY CONDITIONS FOR EXOTHERMIC CHEMICAL REACTIONS}

A better understanding of the potential for exothermic chemical reactions in the waste tanks has been obtained through review of historical process information, analyses of samples, modeling of waste aging processes, and experimental results. This understanding has led to development of an improved characterization approach for addressing the issue of exothermic reactions.

The approach recognizes that a flammable gas deflagration, organic solvent fire, or a condensed-phase (ferrocyanide or organic complexant) exothermic reaction cannot occur unless specific conditions of oxygen or oxidizer, fuel, and temperature (initiators) are all sufficient. Because all three conditions must be sufficient for a chemical reaction to occur, waste can be stored safely if the conditions for reaction are not met. Therefore, the characterization approach is to confirm that one of the conditions of fuel, oxidizer, or temperature (initiators) is not sufficient or that at least one condition is controlled.

An important parameter in controlling condensed-phase reactions is moisture. In sufficient quantity, moisture will prevent condensed-phase (ferrocyanide or organic complexant) propagating reactions by three main mechanisms: (1) moisture behaves as an inert diluent (lowering the effective fuel concentration); (2) moisture prevents initiation of an exothermic reaction (the energy from most credible initiators would be absorbed by the sensible and latent heat of the moisture before the waste reached the critical initiation temperature); and (3) moisture provides a large heat sink that inhibits propagation (for a reaction to propagate, enough energy must be supplied to overcome the sensible and latent heat of the moisture present).

Experiments have shown that moisture can prevent condensed-phase propagating reactions (also see Sections 3.5.1, 3.5.4, and 3.5.5). Adiabatic calorimetry and reaction rate tests on ferrocyanide waste simulants have shown that propagating ferrocyanide reactions cannot occur in waste containing more than $20 \mathrm{wt} \%$ moisture (i.e., $20 \mathrm{wt} \%$ free water ${ }^{1}$ ) (Fauske 1992, Epstein et al. 1994a). Similar experiments using stoichiometric mixtures of organic complexants and nitrate/nitrite salts revealed that propagating reactions will not occur if the moisture content is greater than 20 wt\% (Fauske 1995, Webb et al. 1995).

Sufficient moisture content can ensure that exothermic reactions will not occur, regardless of the fuel-oxidizer concentration. That is, if adequate moisture can be confirmed through monitoring, analysis, or sampling, then it can be concluded that condensed-phase exothermic reactions will not occur, ensuring interim safe storage.

${ }^{1}$ Free water is defined as the water that can be rernoved from samples using standard drying methods by drying at $120^{\circ} \mathrm{C}$ for 18 hours. 
This page intentionally left blank. 


\subsection{TECHNICAL BASIS FOR SAFETY CHARACTERIZATION}

Characterization will provide data for safety decisions relating to exothermic chemical reactions, criticality, tank structure failures from high heat, and worker exposure to noxious vapors. Additional characterization of waste may be needed to guide process controls during retrieval and disposal operations; however, this document focuses specifically on ensuring interim safe storage.

Safety issues posed by stored waste have been extersively studied during the past several years. In general, conservative positions have been taken regarding the potential that a hazard may exist. Additinnal characterization provides data to help quantify risk, confirm conditions, and screen for potential safety issues. Further characterization may also allow relaxation of some constraints. In this section, the technical lases for proposed waste characterizaiion efforts are described.

\subsection{HISTORICAL INFORMATION}

A first step in learning about waste makeup is to evaluate the available information, including process records, waste sample analyses, and waste monitoring data. There are limitations involved in using historical data, and these limitations need to be clearly understood before historical data are used for resclution of the safety issues. Examples of the use of historical data are:

- The Watch List (WHC 1994) was formulated from a study of histcrical information (see Appendix A for a listing of the Watch List tanks).

- Tanks that received ferrocyanide waste were identified from a study of scavenging campaign process records (Borsheim and Simpson 1991).

- Upper-bound ferrocyanide concentrations from process flowsheets, minimum moisture data from historical information, and available waste sample analyses were used to c'rse the ferrocyanide Unreviewed Safety Question (Postma et al. 1994a).

- Tanks that received organic complexants were identified from a study of historical sampling data and waste transfer records (Toth et al. 1994).

- A review of waste level data identified tanks that may undergo episodic releases of trapped gases and could therefore pose a flammable gas hazard (Hopkins 1994). A detailed histotical report on the Flammable Gas Watch List tanks was also completed (Bragei 1994).

To help prioritize those tanks requiring additional characterization, evaluations will continue to look for waste tanks that may have conditions outside the approved safety envelope. 
Future efforts will include, but will not be limited to: (1) review of the specific gravity and rheological data to determine which waste may have a potential to retain flammable gases;

(2) review of in-tank photographs to judge whether a surface $\mathrm{li}_{1}$ uio is present;

(3) examination of stabilization histories and liquid level monitoring to determine which tanks have the potential for mixing organic solvents and waste solids; and (4) assessment of heat load, temperature, and ventilation histories to determine, which tanks may contain dry waste.

\subsection{MODELS GUIDING SAFLTY CHARACTERIZATION}

Characterization of waste solely by the analysis of samples would require extensive sampling. Therefore, an understanding of physical and chemical processes has been used to develop safe storage models that guide characterization. Confidence in these models can be increased by using sampling data and monitoring information. Generalized conclusions on waste conditions may be appropriate within a waste type, within a tank, or across a family of similar tanks, depending on the model and the confidence in the model.

Waste models have been developed to estimate tank heat loads, distribution of heat-producing radionuclides, moisture concentration and distribution, and fuel concentration and distribution. Models discussed in the following sections are not necessarily mathematical models, but may only be conceptual models that are used to apply physical and chemical principles.

\subsection{FLAMMABLE GASES AND NOXIOUS VAPORS}

The primary hazards associated with gases and vapors contained in the tank headspaces are flammalility and toxicity. Chemical decomposition reartions occurring in waste are known to produ se gases that are potentially flammable (hydrogen, nitrous oxide, ammonia, etc.). In addition, organic solvent vapors that may be present in some tanks can contribute to headspace flammability. Ammonia and other vapor species may also represent a noxious vapor hazard. The characterization methods required to address these two nazards are closely related, and thus the two hazards are discussed in this section.

\subsubsection{Flammable Gas Hazard}

Flammable gas species (mainly hydrogen, nitrous oxide, and ammonia) are prodizid at low rates by radiochemical and thermochemical degradation reactions in waste. Vapor from organic solvent may also contribute to headspace flammability. While the mixture of gases may be of flammable composition, a flammability hazard can exist only if a significant amount of gas (i.e., enough to exceed a minimum fuel concentration, known as the lower flammability limit [LFL], in the headspace) can be retained within the tank. Otherwise, the gases will be dissipated to the atmosphere at concentrations too low to represent a flammability hazard. 
For flammable gas to ignite and burn, it must be mixed with an oxidizer and provided sufficient energy to start the chemical reaction. A sufficiently dilute mixture of flammable gas (i.e., a concentration below the LFL) and oxidizer will not burn. The Nationai Fire Protection Association recommends that processes be controlled so that flammable gas concentrations are less than 25\% of the LFL. U.S. Department of Energy orders require that Hanford Site waste tanks be operated within National Fire Protection Association guicelines; therefore, managemeni efforts must provide assurance that flammable gas levels are maustained below $25 \%$ of the LFL.

The hazard can be classified according to the mode by which the flammable gases are released from the waste. For a steady-state release, gases are released at approximately the rate at which they are formed, and the concern is an accumulation of flammable gases in the headspace (i.e., a steady-state flammability hazard). For a limited number of tanks, gases are released episodically at comparatively high rates. For these episodic releases, flammable gas concentrations could exceed $25 \%$ of the LFL for brief time periods. Twenty-five Hanford Site waste tanks are on a Flammable Gas Watch List (see Appendix A for listing) because the waste in these tanks is believed to have the potential to retain hydrogen gas until appreciable quantities are released (Hopkins 1994).

The headspaces of tanks on the Flammable Gas Watch List (see Appendix A for listing) will be monitored for flammable gases continuously. Standard hydrogen monitoring systems have been designed, built, and installed on about a fourth of the Flammable Gas Watch List tanks, and installation of the systems on all of the Flammable Gas Watch List tanks will be completed by April 1995. The standard hydrogen monitoring system consists of a cabinet with piping and instrumentation that support an on-line hydrogen detector and a "grab sampler" (WHC 1992). The grab sampler allows gas samples to be removed from the tank for highly detailed analyses. Therefore, the system allows for both continuous gross measurements of the hydrogen concentration, and precise snap-shots of the gas concentrations. Monitoring results thus far have shown no flammable gas concentrations above $25 \%$ of the LFL (Wilkins 1995).

3.3.1.1 Steady-State Release of Flammable Gas. All DSTs are actively ventilated, and air exchange is rapid enough (except during an episodic release, see Section 3.3.1.2) to keep steady-state bulk hydrogen concentrations in the headspaces well below $25 \%$ of LFL (Graves 1994). However, most SSTs are passively ventilated and only exchange air with the environment through relatively slow barometric pressure changes and by instrument air purges. Therefore, potential accumulation of flammable gases in the headspaces and risers of all SSTs has been explored.

Preliminary studies (Wood 1993, Graves 1994, Fowler and Graves 1994) have examined accumulation of flammable gases in the headspaces and risers of SSTs that are not on the Flammable Gas Watch List. A more detailed study on flammable gas accumulation is currently being developed by the Flammable Gas Program. However, calculations performed thus for show that gas production and release rates from thermochemical and radiochemical pr:-asses are modest and that passive ventilation alone will keep the 
headspaces well below $25 \%$ of the LFL. The contribution to the flammable gas mixture from organic solvent vapor is low (Claybrook and Wood 1994) because the bulk of organic solvent remaining in any tank would likely have a low vapor pressure. Sampling data from tank 241-C-103, which contains a floating organic layer, supports this conclusion. Vapors from the organic solvent amount to less than 5\% of the LFL (Huckaby and Story 1994, Postma et al. 1994b).

Sampling is bein $\bar{\xi}$ used to conîrm that flammable gas does not accumulate in the SSTs. Headspace sanpling results from 30 SSTs (none of which are on the Flammable Gas Watch List) indicate that fiammability in the keadspaces and risers is well below $25 \%$ of the LFL. Headspace sampling of passively ventilated SSTs for flammable gases will continue until all are sampled. Ncre of these tanks is expected to contain steary state flammable gas concentrations above $25 \%$ of the LFL. However, if concentrations greater than $25 \%$ of the LFL are measured during the sampling campaign, then these tanks become candidates for continuous gas monitoring (see Section 3.3.1.2) and potential mitigation.

3.3.1.2 Episodic Release of Flammable Gas. The ability of waste to retain large amounts of gas is dependent on its physical properties and chemical/radiological composition. The waste retains gases that increase the waste volume (slurry growth) until the gases escape. Slurry gas is only present in a tank headspace at high concentrations when it is released by the waste; therefore, the most direct way to characterize gas may be to sample the waste dire:tly.

The amount of gas retained in the waste will be estimated from analysis of tank operational data. Tank monitoring data include changes in surface level (resulting from gas release events and changes in atmospheric pressure) and axial waste temperature profiles. New, more accurate level gages and instrument trees (that measure temperature) are being installed in Hanford Site tanks. Data from these devices will help identify any tanks (in addition to those already on the Flammable Gas Watch List) that have meaningful episodic releases of flammable gas.

Analyses of stored gas are underway for the existing Watch List tanks as well as for non-Watch List tanks. 'Three types of models (Spore et al. 1994) have been used to estimate the stored gas in DSTs--the "maximum historic level drop," the "neutral buoyancy" and the "Rayleigh-Taylor Instability" models. Analyses for SSTs have only used the maximum historic level drop method (Nichols 1994).

\subsubsection{Noxious Vapor Hazaid}

Several health and safety issues are related to noxious vapors that may be present in some of the high-level waste tanks at the Hanford Site. Until vapors in the waste tanks are well characterized, the risks to worker health and safuty cannot be determined or controlled (Osborne and Huckaby 1994). 
A tank-by-tank sampling approach is being pursued to resolve the headspace issues dealing with flammability (see Section 3.3.1.2) and noxicus vapors. Vapor sampling will be conducted on the 177 tanks in the tank farm complex. Modeling and vapor data from tank 241-C-103 indicate that the tank headspaces are well mixed (see Appendix B for discussion), excepi during an episodic gas release. To corroborate that the headspaces are well mixed, additional headspace sampling at different vertical and horizontal locations will be conducted in selected tanks (see Appendix B for discussion).

If any compounds with toxicological properties exceed their respective trigger points inside a tank riser, then Industrial Hygiene is advised that compounds of toxicological concern are present in the tank headspace. The trigger point has been defined as $50 \%$ of the appropriate Consensus Exposure Standard (CES) concentration for all analytes of interest. A CES is generally defined as the most stringent of known regulatory or recommended toxicological values for the occupational setting, including the threshold limit value, permissible exposure limit, recommended exposure limit, and biological exposure limit (Usborne and Huckaby 1994).

The data required to assess toxicity are as follows: (1) identification of chemical compounds of worker health and safety or toxicological importance in the tank headspace; (2) estimates of the concentrations of these toxicologically significant compounds in the headspace; and (3) understanding of the toxicological effects of these compounds and the CES for each constituent of concern.

\subsection{ORGANIC SOLVENTS}

\subsubsection{Organic Solvent Hazard}

Various separation processes involving organic solvents have been used at the Hanford Site. These organic solvents were inadvertently and/or purposely sent to the underground storage tanks, and subsequent waste transfer operations might have distributed organic solvent among several of the 177 high-level waste tanks (Sederburg and Reddick 1994). There are three potential hazards associated with organic solvent: (1) contribution to headspace flammability (see Section 3.3.1.1); (2) ignition of an organic solvent pool resulting in overpressurization of the tank and release of radioactive material to the environs; and (3) ignition of organic solvent that is entrained in waste solids.

\subsubsection{Relationship Between Organic Solvent and Organic Vapor}

There is a direct relationship between liquid organic solvent in a tank and the organic solvent vapors found in the headspace. The mass transfer of a semivolatile species in an organic liquid (e.g., dodecane, tridecane, or tributyl phosphate) to the headspace vapor is determined by several parameters, including the mass transfer coefficient, gas-liquid contact area, ventilation flow rate, duration of exposure, and headspace volume. If organic solvent is present, organic solvent vapors should be detectable in a tank headspace, even if the tank is 
actively ventilated. Most SSTs are only passively ventilated (i.e., the ventilation flow rate is quite small); thus the organic solvent vapors should be present at roughly equilibrium concentrations. Indeed, this was the case for tank 241-C-103, which contains a floating organic solvent pool. Analyses of the liquid organic solvent pool and the vapors in the headspace (see Appendix C) suggest that semivolatile concentrations are present at close-toequilibrium concentrations in the tank headspace.

Currently, one tank (241-C-103) is known to contain an organic solvent pool. Additional tanks that may contain an organic solvent pool will be identified through continued vapor sampling of the tank headspaces. These analyses have been integrated into the noxious vapor

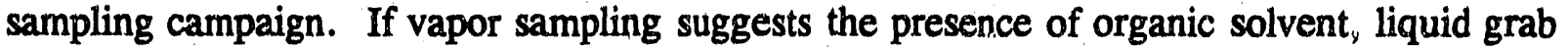
samples and/or surface samples will be obtained to better quantify the potential for an organic solvent fire.

\subsubsection{Entrained Organic Solvent}

Organic solvents that have become entrained in waste solids as a result of interim stabilization or tank leakage may also pose a hazard. Entrained solvents could allow wicking of the organic solvent, resulting in a sustained organic solvent fire. Only small initiators would be required to produce a wick-stabilized flame. However, if the organic solvent is entrained below the waste surface, mass transport (wicking) to the surface for combustion with headspace air is suppressed. In additicn, ignition is less likely below the waste surface (see Section 3.5.3), and once ignition is ruled out, entrained solvent is no longer a hazard.

Waste that may contain entrained organic solvent will be identified through vapor sampling of the tank headspaces. Vapor sampling for organic solvent is being conducted as part of the noxious vapor sampling campaign. If vapor sampling suggests the presence of organic solvent, liquid grab samples will be obtained through the saltwell screen (if possible) to better quantify the potential for an organic solvent fire. Samples of the waste will be obtained to determine if the saturated region is near the surface, and to determine the quantity of entrained organic solvent.

\subsection{FULL-NITRATE (CONDFNSED-PHASE) REACTIONS}

During the defense mission at the Hanford Site, organic complexants and ferrocyanide were sent to the high-level waste tanks. These compounds have the potential to act as a fuel when combined with an oxidizer. Nitrate salts have also been precipitated in the tanks and are a source of oxidizer. Fuel-nitrate/ritrite reactions can propagate at temperatures above a critical onset temperature; therefore, temperatures will be monitored. 


\subsubsection{Safety Criteria}

For a propagating reaction to occur, a mixture of fuel and oxidizer must experience an initiator of sufficient energy (Cady 1993). However, fuel, oxidizers, and temperature (initiators) are all important parameters. If fuel, oxidizer, and temperature (initiators) are not sufficient, then a propagating reaction cannot occur (see Section 2.0). In addition, a reaction cannot propagate if adequate moisture is present, even when the fuel-oxidizer mixture is sufficient (Fauske 1992, Epstein et al. 1994a, Fauske 1995).

Specific conditions of fuel, moisture, and temperature are all required to support a propagating reaction. The minimum required fuel concentration has been determined using a contact-temperature ignition model (Fauske 1995). A necessary (but not sufficient) condition for a condensed-phase propagating chemical reaction is that the fuel concentration be greater than $1200 \mathrm{~J} / \mathrm{g}$, on an energy equivalent basis (Fauske 1995). For fuel concentuations between 1200 and $2100 \mathrm{~J} / \mathrm{g}$, the waste moisture content required to prevent a propagating reaction varies linearly from 0 to $20 \mathrm{wt} \%$. Above $20 \mathrm{wt} \%$, the fuel-moisture linear relationship no longer holds because the mixture becomes liquid continuous. A stoichiometric fuel-oxidizer mixture will not propagate when the moisture content exceeds 20 wt\% (Fauske 1995).

In summary, safe storage criteria for the condensed-phase propagating chemical reaction safety issues (i.e., for ferrocyanide-nitrate/nitrite and organic complexant-nitrate/nitrite reactions) are as follows:

Table 3-1. Safe Storage Criteria.

\begin{tabular}{|c|c|c|}
\hline Parameter & Criteria & Units \\
\hline Fuel Concentration & $\leq 1200$ & $\mathrm{~J} / \mathrm{g}$ \\
\hline Waste Moisture Conient & $\geq 0.022$ Fuel Concentration - 27 & $\mathrm{wt} \%$ \\
\hline
\end{tabular}

\subsubsection{Heat Ioads}

The radioactive decay heat in waste tanks is important to safety primarily because if determines the steady waste temperature profile, and secondarily because it influences the moisture loss rate. A propagating chemical reaction could be initiated in dry waste that contains sufficient fuel when the local umperature rises ubove $200^{\circ} \mathrm{C}$ (Webb et al. 1995). Waste temperature data and a model of heat transfer process ${ }^{-}$have been used to estimate heat loads for the SSTs (Crowe et al. 1993, McLaren 1994a and 1994b). Except for tank 241-C-106, the tanks are passively cooled to below the waste boiling point and do not require moisture for cooling to remain below the reaction initiation temperature. Therefore, initiation of propagating reactions from bulk self-heating is not credible.

Radinactive decay heat in the Hanford Site tanks is decreasing over time. Consequently, waste temperatures will continue to decrease unless the waste thermal properties change because of dryout. The maximum waste temperatures in tanks with active cooling are 
bounded by the temperatures in tank 241-C-106. Even if cooling were lost to this tank, heat transfer modeling has shown that it would take about 480 days to reach the administrative temperature limit of $149^{\circ} \mathrm{C}$ (Kummerer 1994), an adequate time to take mitigative action.

\subsubsection{Imitiators}

If the waste has a sufficient fuel-nitrate mixture and low moisture content (see Section 3.5.1), a propagating reaction could be initiated if an energy source raised the temperature to the ignition point. The potential for tank farm equipment and operations to initiate propagating reactions has been evaluated. Operations that were considered in this evaluation are described in Bajwa (1994) and Scaief (1991).

Operational incidents were considered by using a "what if" approach that focused on incidents that would significantly increase the amount of energy deposited in the tank or waste. These conditions included the following: (1) bringing hot oujects in contact with the waste; (2) operational incidents that would significantly increase the electrical or mechanical power output of equipment in or near the waste; and (3) loss of cooling provided to equipment in or near the waste. Energy from natural events, such as lightning strikes, was also considered. The results of the evaluation are summarized in Table 3-2.

Table 3-2. Summary of Operations Evaluation.

\begin{tabular}{|c|c|c|c|}
\hline Operation & Incident Conditions & $\begin{array}{l}\text { Location of } \\
\text { Heating }\end{array}$ & $\begin{array}{l}\text { Heating } \\
\text { Potential }\end{array}$ \\
\hline In-tank instrumentation & Electrical overcurrent & Waste surface & Negligible \\
\hline Still camera photography & $\begin{array}{l}\text { Dropping flash unit onto } \\
\text { the waste surface, hot } \\
\text { filament contacts waste }\end{array}$ & Waste surface & Localized heating is possible \\
\hline Video camera & $\begin{array}{l}\text { Dropping light unit onto } \\
\text { the waste surface, hot } \\
\text { filament contacts waste }\end{array}$ & Waste aurface & Localized heating is possible \\
\hline $\begin{array}{l}\text { Interim stabilization using } \\
\text { a submersible pump }\end{array}$ & $\begin{array}{l}\text { Loss of cooling to the } \\
\text { motor/pump assembly } \\
\text { causes overheating }\end{array}$ & Bottom of saltwell & $\begin{array}{l}\text { High localized waste } \\
\text { lemperatures are not expected }\end{array}$ \\
\hline $\begin{array}{l}\text { Core sampling - rotary } \\
\text { mode }\end{array}$ & $\begin{array}{l}\text { Loss of bit cooling, } \\
\text { failure to shut down drill } \\
\text { sainpler causes frictional } \\
\text { heating of the waste }\end{array}$ & Bit/waste interface & $\begin{array}{l}\text { Localized heating to ignition } \\
\text { temperatures is possible, safety } \\
\text { interlocks are designed to limit } \\
\text { waste tomperature rise }\end{array}$ \\
\hline $\begin{array}{l}\text { Vehicle operation above } \\
\text { the tank }\end{array}$ & $\begin{array}{l}\text { Rupture of fuel tank on } \\
\text { aboveground equipment, } \\
\text { fuel leakage into the tank, } \\
\text { subsequent fire }\end{array}$ & Waste surface & $\begin{array}{l}\text { Localized heating to ignition } \\
\text { temperatures is possible, but } \\
\text { can be prevented by controls } \\
\text { or skid plates on vehicles }\end{array}$ \\
\hline Lightning strikes & $\begin{array}{l}\text { Lightning strike on or } \\
\text { near a tank or equipment } \\
\text { causes lightning current to } \\
\text { reach the waste }\end{array}$ & $\begin{array}{l}\text { Arc to waste surface } \\
\text { or from immersed } \\
\text { object to waste } \\
\text { below the surface }\end{array}$ & $\begin{array}{l}\text { Local heating to ignition } \\
\text { temperatures is possible, but } \\
\text { can be prevented by grounding }\end{array}$ \\
\hline
\end{tabular}


All of the potential initiators would occur near the waste surface, with the exception of rotary core drilling incidents and lightning. Although rotary core drilling incidents and lightning strikes cannot be deemed incredible initiating events, the risk can be mitigateci with controls. The rotary core driller is designed with safety interlocks that limit drill bit temperature rise. Ignition from lightning strikes can be prevented by grounding. A plan to ground tanks suspected of containing insufficient moisture is being studied. With mitigation of the threat from rotary drilling and lightning strikes, the condition of waste near the surface is the most important factor in determining the risk of fuel-nitrate reaction accidents.

To better understand what the characterization n $ə e d s$ are, it is necessary to determine the depth of "near surface." Preliminary calculations (see Appendix D) have examined heat transfer through waste in contact with a high-temperature initiation source. These calculations suggest "near surface" is the top 2 to $14 \mathrm{~cm}$ of waste. A more rigorous study, to be completed in June 1995, will examine potential accident scenarios to better quantify "near surface."

\subsubsection{Moisture in Waste Sludges}

Moisture is an effective diluent and its sensible and latent heat can prevent reaction propagation. Physical-chemical properties and storage conditions foster the retention of moisture in waste sludge. Sludge is formed when solutions containing transition metals such as iron and other metals are made alkaline. Hydrated oxides and hydroxides are precipitated as fine particles. After settling and consolidation into a sludge layer, moisture is retained by the following mechanisms:

- Interstitial liquid held by physical-chemical forces in the sludge

- Moisture held as hydrates in waste salts.

Experiments (on real waste and simulants) and theoretical calculations have been performed to help quantify the moisture content and retention capability of waste sludges

(Simpson 1994, Jeppson and Wong 1993, Ejsstein et al. 1994b). Results indicate that sludge may be viewed as a concentrated aqueous suspension of fine precipitate particles. Sludge is similar to silty soil, mud, clay or even toothpaste. In such suspensions, strong physicalchemical forces act between the fluid and particles and between particles. Enormous forces must be applied to remove even small quantities of liquid from the matrix of the micronsized sludge particles.

3.5.4.1 Moisture Retention in Waste Sludges. Experiments have been performed on simulants (Meacham et al. 1994a) and actual waste sludge (Simpson 1994) to develop a model for moisture retention (i.e., a consolidation model). The consolidation model and data from drying experiments were used in an analysis of potential drying mechanisms (Epstein et al. 1994b). The analysis concluded that the formation of a dry local or global region of sludge as a result of tank leakage (draining of interstitial liquid) is highly unlikely. Drainage from a waste tank would not dry sludge below about 40 wt \% moisture. Analyses 
have also shown that the formation of dry local region in sludge by hot spots is highly unlikely and that moisture remains uniformly distributed because of capillary forces and moisture migration (Crippen 1994, Epstein et al. 1994b).

The hydrophilic nature of waste sludges is supported by sampling results. A study that examined all of the sludge sampling data available (a total of 135 samples) concluded that the moisture content of waste sludges ranged between 18 to 65 wt\% (Toth et al. 1995). Analyses of core samples from sludge tanks 241-C-108, -109, -112, T-107 and -111 (WHC 1995, Simpson et al. 1993a and 1993b, Valenzuela and Jensen 1994, Simpson 1994) also support the conclusion of uniform moisture distribution.

3.5.4.2 Evaporative Moisture Loss in Sludges. Evaporation of moisture from the waste surface and natural convection between the tank headspace and the outside air are the primary mechanisms for moisture loss in waste sludges. Moisture is lost from sludge as convective processes remove heat from the sludge surface. The proportion of heat removed by each process depends on the salt concentration in the pore fluid (which lowers the water vapor pressure), the radioactive decay heat, and the natural (or forced) convection exchange with the environment. Waste that has the greatest potential for global dryout would be that stored in high-heat-load tanks, in tanks with forced ventilation, or in tanks that only contain a small amount of waste (less than $20 \mathrm{~cm}$ deep).

A tank-by-tank evaluation has been performed for passively and actively ventilated tanks (Webb et al. 1995) to estimate the moisture loss rate. The loss rates have been combined with the estimates of current moisture to predict moisture retention for an additional 50 years of storage. Tanks containing waste predicted to dry below safe levels have been identified for further evaluation and possible controls.

Considerable knowledge is available on moisture migration and moisture retention behavior in sludge-like materials. With only a few exceptions, sludges retain significant moisture, and dryout mechanisms are not significant for tanks with low radioactive decay heat. Sampling of sludges to date has verified that sludges retain considerable moisture. Therefore, further sampling for chemical reactivity safety concerns is focused on surface moisture in the few exceptional, potentially dry sludge tanks. Sampling of sludge tanks expected to retain significant moisture is given a low priority. Because moisture tends to be uniformly distributed in sludges (see references and discussion Section 3.5.4.1), surface sampling is deemed adequate for characterizing waste moisture. Full-depth core sampling of sludges is not necessary for determining sludge moisture and is not emphasized in the new approach to safety characterization; however, analyses of full-depth core sludge samples for moisture content will continue in order to reinforce the conclusion of uniform moisture distribution.

\subsubsection{Moisture in Saltcake Waste}

Moisture is retained in saltcake by physical-chemical forces and as hydrates. However, the forces holding moisture in saltcake waste are far weaker than those exhibited in waste sludges (Atherton 1974, Handy 1975, Metz 1975b, Kirk 1980, Epstein et al. 1994b). Less is 
known about the moisture content and profiles in saltcake than for sludge, in large part because of limited sample data. It is important to note that the concern is with the moisture content of saltcake after removal of pumpable liquids. Waste that still has a supernatant (aqueous liquid layer) contains too much moisture to support a propagating reaction.

3.5.5.1 Moisture Retention in Saltcake Waste. The moisture drainage and retention characteristics of Hanford Site saltcake waste were studied in the 1970's as part of the interim stabilization campaign. Several studies examinod saltcake porosity, capillary height, and residual moisture in saltcake after drainage (Atherton 1974, Handy 1975, Metz 1975a and 1976, Kirk 1980).

Porosity estimates for Hanford Site saltcakes have ranged between 30 and $48 \%$, but pumping experience indicates a porosity in excess of 30\% (DeWeese 1988). The best estimate for capillary heights in saltcake waste is only 15 to $61 \mathrm{~cm}$ (sludges can have capillary heights of over $610 \mathrm{~cm}$ ). During interim stabilization, most of the interstital liquid will simply drain from the saitcake until it reaches the saturated zone dictated by the capillary height. However, some moisture will exist throughout the saltcake when the maximum amount of interstitial liquid has been removed by pumping (Handy 1975, Metz 1975a and 1975b).

The interstitial liquid remaining after drainage will occupy 10 to $20 \%$ of the saltcake void volume (Handy 1975, Metz 1975a and 1975b, Klem 1990). Using a specific gravity of 1.4 for the interstitial liquid and 2.3 for the solids (Fleming 1958), and a porosity of $35 \%$, at least 1.7 to $3.3 \mathrm{wt} \%$ moisture would be expected to remain in saltcake after drainage. Data from saltcake tanks that have been interim stabilized have shown greater moisture retention (Neskas and Borsheim 1993, Boyles 1990). For example, analyses of the top $15 \mathrm{~cm}$ of saltcake in tank 241-BY-104 in 1992, eight years after interim stabilization, revealed a moisture content of 15 to 17 wt\% (Neskas and Borsheim 1993). Although residual moisture in saltcake cannot be removed by any direct flow process, moisture could be remuved by evaporation (Handy 1975).

3.5.5.2 Evaporative Moisture Loss in Saltcake. Once saltcake waste has been drained to some irreducible amount, additional moisture can be lost through evaporation. Contrary to what was discovered for waste sludges, saltcake waste does not dry globally, and it is possible to have moisture gradients. However, a lower bound moisture content for saltcake is established by the equilibrium moisture content at the local temperature and relative humidity. Experimentation (Postma et al. 1994a, Fauske 1994) has shown that for an average Hanford Site relative humidity of $55 \%$, the sodium hydroxide concentration controls the minimum moisture content. Only limited data are available for saltcake composition, and these show typical sodium hydroxide concentrations of only a few percent. Using these values for sodium hydroxide concentration, the minimum moisture level of saltcake waste at equilibrium would only be about 5 wt \%.

Saltcake waste does not intrinsically retain sufficient moisture (i.e., greater than $20 \mathrm{wt} \%$ ) to completely rule out propagating chemical reactions; therefore, further characterization is required. Monitoring for temperature and moisture will continue, and additional safety 
characterization will include fuel and moisture determination from sampling. Efforts will focus on the waste surface, which is at greatest risk for ignition (see Section 3.5.3). Data on fuel and moisture content will be collected from auger and grab sampling as appropriate. Moisture monitoring may include liquid observation well scans with neutron probes' (Watson 1993) and electromagnetic induction (EMI) probes (Toffer 1995), and possibly surface scans using IMI or near-infrared probes.

\subsubsection{Fuel in Wraste}

Ferrocyanide fuels are only found in sludge, and from historic records it is known that only 18 SSTs originally contained significant ferrocyanide (Borsheim and Simpson 1991). The ferrocyanide tanks have low heat loads (McLaren 1994a and 1994b, Crowe et al. 1993), are passively ventilated, and contain at least $60 \mathrm{~cm}$ of waste (Hanlon 1994). From the moisture discussion (see Section 3.5.4), sufficient moisture is present in ferrocyanide slidges to prevent propagating chemical reactions.

Organic complexants may be found in sludge or saltcake. As with ferrocyanide, for those cases in which organic complexants are embedded in sludge, sufficient moisture is expected to be present to prevent propagating chemical reactions. However, there is evidence that saltcake does not retain greater than $20 \mathrm{wt} \%$ moisture (see Section 3.5.5). Therefore, the potential for organic complexant-oxidizer mixtures and low moisture cannot be dismissed. A combination of physical modeling and characterization data is required to determine the chemical reactivity of saltcake waste.

3.5.6.1 Distribution of Fuel. Much is known from the process flowsheets (Sloat 1954 and 1955) about how ferrocyanide sludges were formed. Ferrocyanide sludges precipitated as fine particles and took a long time (more than 10 days) to settle, resulting in a fairly homogeneous distribution of fuel in 12-cm-thick layers (Meacham et al. 1994b, Postma et al. 1994a). Therefore, it is possible to make confident conclusions on ferrocyanide fuel content from a limited number of full-depth core samples (Meacham et al. 1994b). Data from experiments (Jeppson and Wong 1993) and full-depth core samples (Simpson et al. 1993a and 1993b, Valenzuela and Jensen 1994, WHC 1995) are consistent with the fuel distribution model. However, similar work on an organic complexant distribution model has not been completed.

Only limited information exists regarding the spatial variability of organic complexants in saltcake. However, the conditions under which saltcake waste was formed are known (waste was partially evaporaied, either in situ or c'ing vacuum evaporators, to reduce waste volume) and the following inferences can be drawn. A liquid-solid slurry formed in the evaporation process, and upon cooling, additional material precipitated from solution as solubility limits were exceeded. The least soluble constituents precipitated initially, and the more soluble constituents remained in solution. Consequently, it is expected that saltcake formed in layers would exhibit little horizontal variability, but could exhibit significant vertical variability. 
A preliminary model for fuel concentration in saltcake has been derived from recently obtained data on the solubilities of significant organic complexants in tank supernatant solutions (Barney 1994). To confirm this model, additional experimentation on organic complexant salt solubilities, sampling of saltcake interstitial liquid, and sampling of the upper surface of saltcake solids will be conducted. Auger or grab sampling could be used to examine whether organic complexants are present in the surface of saltcake waste. It is expected that organic complexants will be in solution in interstitial liquid and that interim stabilization will remove organic complexants from the tanks. The current safety screening logic (see Section 4.1) does not depend on this work.

3.5.6.2 Waste Aging. As discussed earlier (see Section 3.5.4), ferrocyanide waste retains considerable moisture, and full-depth core sampling is not required to verify interim safe storage. However, core sampling does provide useful information on the remaining fuel concentration. Ferrocyanide waste stored in Hanford Site tanks has been exposed to caustic solutions and radiation for nearly 40 years (Babad et al. 1993). Long-term degradation (aging) of ferrocyanide is known to have occurred through fundamental chemical processes in the waste (Lilga et al. 1993 and 1994). Analyses of all the core samples taken from ferrocyanide tanks thus far (this includes tanks 241-C-108, -109, -112, and 241-T-107) revealed fuel values about an order of magnitude less than the original flowsheet concentrations (WHC 1995, Simpson et al. 1993a and 1993b, Valenzuela and Jensen 1994). Additional full-depth cores will be taken from ferrocyanide waste having the least conducive conditions for aging. If the results confirm significant aging has occurred in these tanks, then no more tanks will be sampled to determine ferrocyanide concentration.

Organic complexant and solvent wastes stored in Hanford Site tanks have also been exposed to conditions of high temperatures, radiation, and strong caustic solutions. Experiments on waste simulants have shown that organic complexants and solvents will degrade to less reactive forms when exposed to Hanford Site tank conditions (Camaioni et al. 1994). Additional information on organic aging will be obtained from simulant experiments and sampling. Sampling includes auger and grab samples, and possibly full-depth cores.

\subsection{CRITICALITY}

Safety analyses (Braun 1994) performed for the criticality safety issue concluded that a large margin of subcriticality exists in the current storage mode. This conclusion was based on:

(1) the waste was highly subcritical when it was transferred to the tanks and no credible mechanism was found to concentrate the fissile material preferentially in the tanks;

(2) available sample analyses have shown concentrations of fissile material that are orders of magnitude below the minimum critical concentration (the highest $\mathbf{k}_{\infty}$ calculated was only about 0.1); and (3) the fissile material was accompanied by an excess of neutron absorbers when placed in the tanks, which would help maintain subcriticality. 
Sampling specifically for criticality is not required to maintain interim safe storage. However, analyses for fissile material will be conducted on sludge waste samples as they become available, regardless of whether the sampling was performed for safety characterization, pretreatment, or retrieval. These analyses will be used to help reinforce the conclusion on subcriticality.

\subsection{HIGH HEAT}

The high-heat safety issue is focused on the potential for release resulting from a heatinduced structural failure of a tank. This includes only SSTs, because the DSTs were designed for safe storage of high-heat waste. There are eight tanks (Rander 1994) with heat loads above 11,700 watts, the heat load criteria for SSTs (Pauly and Torgerson 1987). Of these $\tan ^{1}$, only tank 241-C-106 requires forced cooling to keep temperatures below $149^{\circ} \mathrm{C}$, and this tank is the only high-heat tank on the Watch List (see Appendix A).

All of the high-heat tanks can be identified through temperature measurements and thermal modeling, and additional chemical speciation to identify potential high-heat tanks is not necessary.

\subsection{AMOUNT OF CHARACTERIZATION REQUIRED}

To determine how much characterization is required, a cost/benefit analysis is necessary. A cost/benefit analysis incorporates analyses that describe: (1) a set of mitigation options available for each tank (one option always included is to do nothing); (2) the consequences of each mitigation option given the true state of the tank; (3) the "costs" of each consequence and mitigation option, expressed in a common unit (such as dollars or man-rem exposure); and (4) the currently estimated state of a specific tank (i.e., moisture and fuel content). 


\subsection{APPROACH TO SAFETY SCREENING}

Several factors strongly influence the approach to safety screening. Experiments and analyses have shown that a minimum energy equivalent fuel content of $1200 \mathrm{~J} / \mathrm{g}$ is required to support a propagating reaction. Studies also indicate that moisture content greater than 20 wt\% will prevent condensec-phase propagation, even if the conditions of fuel and uxidizer are sufficient. Ileadspace vapor sampling can identify tariks containing organic solvent. Headspace sampling and/or monitoring can also identify tanks containing significant quantities of flammable gas or noxious vapors. The focus of safety screening thus becomes:

- Detecting flammable gases, noxious vapors, and organic solvents through headspace vapor sampling

- Determining waste surface noisture content through sampling or in situ moisture monitoring

- Determining fuel content, if the moisture content is below $20 \mathrm{wt} \%$.

Headspace vapor sampling or ongoing vapor monitoring will be used to identify gas phase safety issues. Moisture content can be determined by sampling, surveillance (surface liquid), or monitoring. Fuel content may be predicted from historic information, but this will need to be corroborated by sampling the headspace, supernatant, interstitial liquid, and/or condensed phase.

\subsection{SAFETY SCREENING LOGIC}

The logic chart for safety screening is shown in Figure 4-1 and the screening steps are discussed below. The details and justification for the information required to make decisions are discussed in Section 3.0.

Step 1: Tank-by-tank evaluations of process flowsheets, waste transfer records, historic and present monitoring data, and available sampling results will be performed. This information will help prioritize tanks for further evaluation. If it can be concluded from these evaluations that waste conditions are within the approved safety envelope for safe storage and worker protection guidelines, then sampling would be limited to that required to ensure that waste conditions remain within the sefety envelope (Step 8). Evaluations will continue in parallel with screening to ensure that results of ongoing analyses, which may reduce the need to sample, are factored into the screening process. 
Figure 4-1. Safety Screening Logic

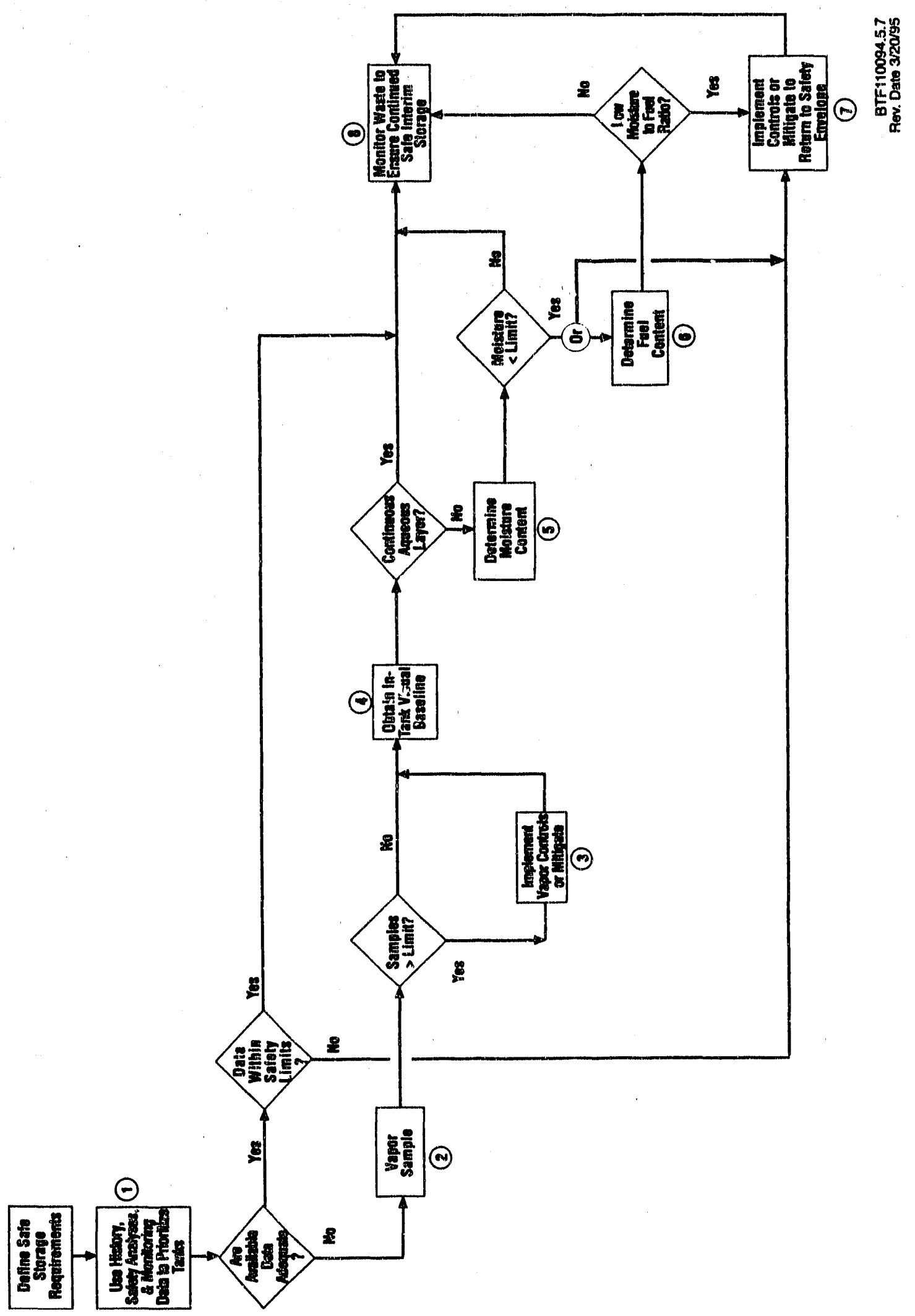


Step 2: $\quad$ Headspace vapor samples will be obtained for three purposes:

2A. Check for flammability. If concentrations exceed pre-determined requirements, additional monitoring, sampling, or mitigation may be required. These mitigation or control actions will be performed in Step 3A. Resampling of the headspace may be required in some cases to ensure effectiveness of mitigation before proceeding to Step 4 .

2B. Check for noxious vapor concentration. Controls may be required if vapors are detected above CFS concentrations, or if any gas phase limits are exceeded (Step 3B).

2C. Determine if tank headspace contains organic solvent vapors. Samples will be analyzed to detect semivolatile organic solvents. Analyses will screen for both anticipated and unexpected analytes. If solvents are detected, the location may be determined or proper mitigation/controls applied (Step 3C).

Step 3: Tank waste that exceeds any limits identified in Steps 2A, 2B or 2C will require implementation of appropriate controls or mitigation as described in Steps $3 A, 3 B$, and $3 C$.

3A. If flammable gases are observed at concentrations greater than $25 \%$ of the LFL, specific controls (WHC 1994) must be implemented during all operations in and above the tank (use of spark-free tools, grounding of conductive items, securing of tools used in or above an open tank). Monitoring will be required during operations. Mitigation (ventilation or inerting) may be required.

3B. If noxious vapors are observed at concentrations greater than the CES, worker safety controls, which may include the use of self-contained breathing apparatus, will be considered. Monitoring will be required during operations. Mitigation (ventilation or inerting) may be required.

3C. Tanks that exceed the limits in Step 2C are expected to contain organic solvents. A liquid grab sample and/or a near-surface sample will be obtained to measure organic solvent concentration. If only low fuel values are present at the waste surface (see Section 3.5.3), then safe storage may proceed without mitigation.

Step 4: Visual inspections of the waste surface will be used as an initial screening for moisture. All DSTs and about five SSTs are expected to fall in this category.

Siep 5: - Waste without a supernatant will require near-surface moisture determination. If the moisture content is less than $20 \mathrm{wt} \%$, the fuel content will be evaluated in step 6. If moisture content is above $20 \mathrm{wt} \%$, but the waste shows a high potential for drying (e.g., because of high temperature), fuel content will be 
evaluated. Otherwise, no further safety screening sampling will be required, and safety screening will proceed to Step 8 . The need for continuous monitoring or periodic sampling will be evaluated for each tank as part of Step 8.

Step 6: If moisture content is not adequate, fuel concentration will be determined for the waste surface. Determination of fuel content in the near-surface samples is expected to be adequate, because credible initiation everits oucur at the waste surface. If fuel content is below $1200 \mathrm{~J} / \mathrm{g}$, safe storage may proceed without mitigation. Otherwise, corrective actions may be required.

Step 7: $\quad$ Mitigation and/or controls will be required if the waste is dry and reactive. The moisture content of the waste will be increased by an approved method, or stringent controls will be implemented to prohibit initiators.

Step 8: $\quad$ Ensuring continued safe storage requires cognizance of possible changes occurring over time. Drying of moist waste must be considered, as well as changes (e.g., increasing waste viscosity) that may lead to retention of flammable gases.

\subsection{DEFICIFNCIES IN THE PREVIOUS APPROACH}

The previous approach to characterization (DOE 1994) did not integrate existing knowledge with the desire to identify potential safety issues. Characterization was based primarily on the assumption that full-depth core sampling would provide the necessary and sufficient information for programmatic decisions on interim safe storage, retrieval, and disposal. Headspace vapor sampling was limited to specific concerns of flammability on a few select tanks. As a result, the initial screening effort focused on obtaining full-depth core samples of tank waste and analyzing the chemical composition to determine whether fuel concentrations exceeded safe concentrations. Shortcomings to this approach include:

- Waste changes over time were not adequately considered.

- Properties of the condensed-phase waste samples taken by core sampling have limited value in predicting problems with the vapor phase; i.e., generation of flammable or noxious gases.

- The approach did not take full advantage of existing data, and underused headspace vapor sampling.

- The limitation in waste sampling equipment was not recognized, and further equipment development is time consuming and costly. 
- Access to the tank waste is limited to locations directly below a few existing access ports, allowirig very few samples to be taken. The samples taken at these locations may not be representative of the total waste volume, because of waste heterogeneity. Physical constraints make it unlikely that an effort to show an: absence of fuei in the waste would be timely and cost-effective.

- Assessments of waste parameters wire to be based only on a few samples of waste. The few samples would have low statistical confidence for some parameters, and models for distribution of many parameters were not available. 
This page intentionally left blank. 


\subsection{RESOLUTION OF EACH SAFETY ISSUE}

Section 4.0 discussed screening of tanks to determine if a safety issue is present. The information obtained will be coupled with other information to ensure that the safety issues are resolved, or the tanks mitigated. This section briefly discusses resolution of specific safety issues using all available sources of information.

- Ferrocyanide

Recent laboratory work with simulantis and core sampling results (see Section 3.5.6) indicate that ferrocyanide degrades (ages) under alkaline conditions. Core sampling will be conducted to confirm aging in those waste tanks having the least conducive conditions for aging (i.e., waste tanks with low pH, low radiation doses, and low temperatures). These results are expected to show that the ferrocyanide has aged to low concentrations that are safe. If this model is confirmed, additional core sampling of all ferrocyanide tanks to ensure interim safe storage will not be required.

- Organic Complexants

Moisture concentration will be controlled and monitored to ensure safe storage of fuel-sufficient organic complexant waste until the waste is retrieved or the organic complexants age to safe concentrations. Models regarding degradation of organic complexants will be further developed and tested, and may support future resolution of the organic complexant safety issue.

\section{- Organic Solvent}

Vapor samples will be used to identify tanks containing organic solvents. If the waste contains a flammable mixture of organic solvent and waste solids that is easily ignited, then mitigation or controls against initiation may be required.

\section{- Flammable Gas Tanks}

Generation, retention and release of flammable gases can be steady-state or periodic phenomena that are not well characterized by single-time sampling events. Standard hydrogen monitoring systems will continuously monitor the headspace of the Flammable Gas Watch List tanks, and installation will be completed in April 1995.

Another part of this safety issue is concerned with the amount of gas that is stored within the waste. Current estimates of the stored gas content come from analysis of surface level and waste temperature data. Based on the experience and analyses for tank 241-SY-101, several methods can be used to estimate the volume of gas stored in the waste. Headspace monitoring will detect steady-state gas release and the episodic releases; however, the episodic re ases will not necessarily release all of the stored 
gas. Direct measurement of the stored gas will be a critical item for resolution of this safety issue.

If the headspace flammable gas concentration exceeds $25 \%$ of the LFL, or if the estimated stored volume exceeds a specified amount (this will be set from safety assessments), mitigative actions must be considered. Monitoring will be conducted until the tank contents are retrieved.

- Noxious Vapors

A tank-by-tank sampling approach is being pursued to resolve the noxious vapor issue. Vapor sampling will be conducted in the headspaces of the tanks at the Hanford Site. If there is a potential for worker exposure to noxious vapors above CES concentrations, worker safety controls will be considered. Headspace monitoring may be required during operations in tanks that have been identified as containing noxious gases. Mitigation (ventilation or inerting) may also be required.

- Criticality

Analyses for fissile material will be conducted on sludge waste samples (taken for safety characterization, pretreatment, or retrieval) as they become available. These analyses will be used to help reinforce the conclusion on subcriticality.

- High Heat

Tank 241-C-106 is the only tank identified as having a high-heat safety issue. The temperature in this tank will be monitored and controlled until retrieval (tank 241-C-106 is the first candidate for retrieval).

\section{- Long-Range Monitoring of Hanford Site Waste Tanks}

It is apparent that long-range monitoring will be required for some of the waste tanks until retrieval and vitrification. This includes near-surface moisture monitoring, continued use of standard hydrogen monitors, headspace sampling, and liquid level, waste level, and temperature monitoring. An outline identifying the scope of longrange monitoring will be completed in mid-April 1995; the outline will also specify a completion date for a long-range monitoring plan. 


\subsection{CONCLUDING REMARKS}

An approach to characterization for screening tank waste for safety issues and resolution of those issues was presented. An examination of the potential safety issues has shown that the information requirements can be met using a combination of data that includes headspace sample analysis, tank historical records, monitoring and surveillance information, experimental results on simulated and real waste, modeling results, sampling of interstitial liquid or supernatant, and aralyses of waste samples.

Judicious temperature monitoring and headspace monitoring will be effective ways to obtain early warning of reactions that have not been predicted. Waste moisture will inhibit reactions, and temperature can be an initiator for exothermic reactions. Ensuring high moisture content or low temperature (i.e., controlling initiators) is an effective approach for preventing both known and unknown reactions.

The information provided in this document was summarized from several sources and gives an overview of the direction of Waste Tank Safety Program characterization. Although the approach to characterization is summarized here, the full technical bases are provided in the individual safety analyses cited in the report. The details on quantity, quality, and frequency of characterization are covered in the data quality objective documents for each specific safety issue. 
This page intentionally left blank. 


\subsection{REFERENCES}

Atherton, J. A., 1974, Prediction of Liquor Retention in Saltcakes and Sludges, ARH-CD-230, Atlantic Richfield Hanford Company, Richland, Washington.

Babad, H., J. E. Meacham, B. C. Simpson, and R. J. Cash, 1993, The Role of Aging in Resolving the Ferrocyanide Safety Issue, WHC-EP-0599, Westinghouse Hanford Company, Richland, Washington.

Bajwa, J. K., 1994, Construction, Maintenance, and Operational Activities Analysis Summarles, WHC-SD-WM-SARR-C09, We inghouse Hanford Company, Richland, Washington.

Bander, T. J., 1994, Evaluation of Heat Sources in High-Heat Single Shell Tanks, WHC-SD-WM-ER-333, Rev. 0, Westinghouse Hanford Company, Richland, Washington

Barney, G. S., 1994, The Solubilities of Significant Crganic Compounds in HLW Tank Supernatant Solutions, WHC-SA-2565-FP, Westinghouse Hanford Company, Richland, Washington.

Borsheim, G. L., and B. C. Simpson, 1991, An Assessment of the Inventories of the Ferrocyanide Watch List Tanks, WHIC-SD-WM-ER-133, Rev, 0, Westinghouse Hanford Company, Richiand, Washington.

Boyles, V. C., 1990, Single-Shell Tank Stabilization Record, WHC-SD-RE-TI-178, Rev. 0, Westinghouse Hanford Company, Richland, Washington.

Brager, H. R., 1994, Summary of Information on Flammable Gas Watch List Tanks, WHC-EP-0711, Westinghouse Hanford Company, Richland, Washington.

Braun, D. J., 1994, High Level Waste Tank Subcriticality Safety Assessment, WHC-SD-WM-SARR-003, Rev. 0, Westinghouse Hanford Company, Richland, Washington.

Cady, H. H., 1993, Evaluation of Ferrocyanide/Nitrate Explosive Hizard, LA-12589-MS, Los Alamos National Laboratory, Los Alamos, New Mexico.

Camaioni, D. M., W. D. Samuels, B. D. Lenihan, S. A. Clauss, K. L. Wahl, and J. A. Campbell, 1994, Organic Tanks Safety Program Waste Aging Studies, PNL-10161, Pacific Northwest Laboratory, Richland, Washington. 
Claybrook, S. W., and S. A. Wood, 1994, Organic Evaporation in Waste Tank C-103, WHC-SD-WM-ER-344, Rev, 0, Westinghouse Hanford Company, Richland, Washington.

Crippen, M. D., 1993, Barometric Prescure Varlations, WHC-EP-0651, Westinghouse Hanford Company, Richland, Washington

Crippen, M. D., 1994, Ferrocyanide Safety Program: Moisture Migration Test in Ferrocyanide Simulant, WHC-EP.0800, Westinghouse Hanford Company, Richland, Washington.

Crowe, R. D., M. Kummerer, and A. K. Postma, 1993, Estimation of Heat Load in Waste Tanks Using Average Vapor Space Temperatures, WHC-EP-0709, Westinghouse Hanford Company, Richland, Washington.

DeWeese, G. C., 1988, Observed Porosities of Single-Shell Tank Waste Saltcakes and Sludges, WHC-SD-WM-TI-328, Rev. 0, Westinghouse Hanford Company, Richland, Washington.

DOE, 1994, Recommendation 93-5 Implementation Plan, DOE/RI, 94-0001, U.S. Department of Energy, Richland Operations Office, Richland, Washington.

Epstein, M., H. K. Fauske and R. J. Cash, 1994a, Conditions for Reaction Propagation in Dried Ferrocyanide/Nitrate-Nitrite Pouders, WHC-SD-WM-TI-619, Rev. 0, Westinghouse Hanford Company, Richland, Washington.

Epstein, M., H. K. Fauske, M. D. Crippen, D. R. Dickinson, J. D. McCormack, R. J. Cash, J. E. Meacham, and C. S. Simmons, 1994b, Ferrocyanide Safety Program: Assessment of the Possibility of Ferrocyanide Sludge Dryout, WHC-EP-0816, Westinghouse Hanford Company, Richland, Washington.

Fauske, H. K., 1992, Adiabatic Calorimetry and Reaction Propagation Rate Tests with Synthetic Ferrocyanide Materials Including U Plant-1, U Plant-2, In-Farm-1, In-Farm-2, and Vendor-Procured Sodium Nickel Ferrocyanide, WHC-SD-WM-RPT-054, Rev, 0, Westinghouse Hanford Company, Richland, Washington.

Fauske, H. K., 1994, Moisture Loss Estimates for Hanford Single-Shell Tanks, FAI/94-114, Fauske and Associates, Inc., Burr Ridge, Illinois.

Fauske, H. K., 1995, The Contact-Temperature Ignition (CTI) Criterion for Propagating Chemical Reactions and Application to Hanford Waste, FAI/94-103, Fauske and Associates, Inc., Burr Ridge, Illinois. 
Fleming, R. F., 1958, A Compilation of Physical and Chemical Properties of Materials and Streams Encountered in the Chemical Process Department, HW-57386, General Electric Hanford Atomic Products Operation, Richland, Washington.

Fowler, K. D., and R. D. Graves, 1994, Decision Analysis for Continuous Cover Gas Monitoring of Ferrocyanide Watch List Tanks, WHC-EP-0743, Westinghouse Hanford Company, Richland, Washington.

Graves, R. D., 1994, Topical Report on Flammable Gases in Nonburping Waste Tanks, WHC-SD-WM-SARR-015, Rev. 0, Westinghouse Hanford Company, Richland, Washington.

Handy, L. L, 1975, Flow Properties of Saltcake for Interstitial Liquid Removal/ Immobilization Development Program, ARH-C-6, Atlantic Richfield Hanford Company, Richland, Washington.

Hanlon, B. M., 1994, Waste Tank Summary for the Month Ending December 31, 1994, WHC-EP-0182-81, Westinghouse Hanford Company, Richland, Washington.

Hopkins, J. D., 1994, Criteria for Flammable Gas Watch List Tanks, WHC-EP-0702, Rev. 0, Westinghouse Hanford Company, Richland, Washington.

Huckaby, J. L., and M. S. Story, 1994, Vapor Characterization of Tank 241-C-103, WHC-EP-0780, Rev. 0, Westinghouse Hanford Company, Richland, Washington.

Jeppson, D. W., and J. J. Wong, 1993, Ferrocyanide Waste Simulant Characterization, WHC-EP-0631, Westinghouse Hanford Company, Richland, Washington.

Kirk, J. J., 1980, Permeability, Porosity, and Capillarity of Hanford Waste Material and Its Limits of Pumpability, RHO-CD-925, Rev. 2, Rockwell Hanford Operations, Richland, Washington.

Klem, M. J., 1990, Single-Shell Tank Interim Stabilization Criteria Review, WHC-SD-WM-DIC-005, Rev. 0, Westinghouse Hanford Company, Richland, Washington.

Kreith, F. and W. Z. Black, 1980, Basic Heat Transfer, Harper \& Row, Publishers, New York, New York.

Kummerer, M., 1994, Topical Report on Heat Removal Characteristics of Waste Storage Tanks, WHC-SD-WM-SARR-010, Rev. 0, Westinghouse Hanford Company, Richland, Washington. 
Lilga, M. A., M. R. Lumetta, and G. F. Schiefelbein, 1993, Ferrocyanide Safety Project, Task 3 Aging Studies, FY 1993 Annual Report, PNL-8888, Pacific Northwest Laboratory, Richland, Washington.

Lilga, M. A., E. V. Alderson, M. R. Lumetta, and G. F. Schiefelbein, 1994, Ferrocyanide Safety Project, Task 3: Ferrocyanide Aging Studies - FY 1994 Annual Report, PNL-10126, Pacific Northwest Laboratory, Richland, Washington.

McLaren, J, M., 1994a, Ferrocyanide Safety Program: Thermal Analysis of Ferrocyanide Tanks, Group I, WHC-EP-0729, Westinghouse Hanford Company, Richland, Washington.

McLaren, J. M., 1994b, Ferrocyanide Safety Program: Thermai Analysis of Ferrocyanide Watch List Tanks, Group II, WHC-EP-0794, Westinghouse Hanford Company, Richland, Washington.

Meacham, J. E., R. J. Cash, and G. T. Dukelow, 1994a, Quarterly Report on the Ferrocyanide Safety Program for the Period Ending September 30, 1994, WHC-EP-0474-14, Westinghouse Hanford Company, Richland, Washington.

Meacham, J. E., R. J. Cash, G. T. Dukelow, H. Babad, J. W. Buck, C. M. Anderson, B. A. Pulsipher, J. J. Toth, and P. J. Turner, 1994b, Data Requirements for the Ferrocyanide Safety Issue Developed Through the Data Quality Objectives Frocess, WHC-SD-WM-DQO-007, Rev. 0, Westinghouse Hanford Company, Richland, Washington.

Metz, W. P., 1975a, Capillarity Demonstration, (internal memorandum to R. C. Roal, March 26), Atlantic Richfield Hanford Company, Richland, Washington.

Metz, W. P., 1975b, Preliminary Evaluation of the Affects of Capillary Forces on Stabilizing Hanford Waste Saltcakes and Sludges, (internal memorandum to R. J. Thompson, September 9), Atlantic Richfield Hanford Company, Richland, Washington.

Metz, W. P., 1976, A Topical Report on Interstitial Liquid Removal From Hanford Saltcakes, ARH-CD-545, Atlantic Richfield Hanford Company, Richland, Washington.

Neskas, J. W., ard G. L. Borsheim, 1993, Data Interpretation Report on Tank 241-BY-104 Auger Samples, WHC-SD-WM-RPT-068, Rev. 0, Westinghouse Hanford Company, Richland, Washington.

Nichols, B. D., S. W. Eisenhawer, and J. W. Spore, 1994, Bounding Gas Release Calculations of Flammable Gas Watch List Single-Shell Tanks, LA-UR-94-1323, Los Alamos National Laboratory, Los Alamos, New Mexico. 
Osborne, J. W., and Huckaby, J. L., 1994, Program Plan for the Resolution of Tank Vapor Issues, WHC-EP-0562, Rev. 1, Westinghouse Hanford Company, Richland, Washington.

Pauly, T. R., and M. M. Torgerson, 1987, Tanks 105-C and 106-C Stabilization Study, RHO-RE-EV-97, ñockwell Hanford Operations, Richland, Washington.

Pool, K. H., and R. M. Bean, 1994, Analysis of Liquid Samples from Hanford Waste Tank 241-C-103, PNL-9403, Pacific Northwest Laboratory, Richland, Washington.

Postma, A. K., J. E. Meacham, G. S. Barney, G. L. Borsheim, R. J. Cash, M. D. Crippen, D. R. Dickinson, J. M. Grigsby, D. W. Jeppson, M. Kummerer, J. M. McLaren, C. S. Simmons, and B. C. Simpson, 1994a, Ferrocyanide Safety Program: Safety Criteria for Ferrocyanide Watch List Tanks, WHC-EP-0691, Westinghouse Hanford Company, Richland, Washington.

Postma, A. K., D. B. Bechtold, G. L. Borsheim, J. M. Grigsby, R. L. Guthrie, M. Kummerer, M. G. Plys, and D. A. Turner, 1994b, Safety Analysis of Exothermic Reaction Hazards Associated with the Organic Liquid Layer in Tank 241-C-103, WHC-SD-WM-SARR-001, Rev. 0, Westinghouse Hanford Company, Richland, Washington.

Scaief, C. C., 1991, Hydrogen Ignition Capability of Tank Farm Instrumentation \& Electrical Equipment, WHC-SD-WM-ES-176, Rev. 0, Westinghouse Hanford Company, Richland, Washington.

Sederburg, J. P., and J. A. Reddick, 1994, TBP and Diluent Mass Balances in the Purex Plant ai Hanford 1955 - 1991, WHC-MR-0483, Rev. 0, Westinghouse Hanford Company, Richland, Washington.

Simpson, B. C., G. L. Borsheim, and L. Jensen, 1993a, Tank Characterization Report: Tank 241-C-109, WHC-EP-0668, Westinghouse Hanford Company, Richland, Washington.

Simpson, B. C., G. L. Borsheim, and L. Jensen, 1993b, Tank Characterization Data Report: Tank 241-C-112, WHC-EP-0640, Rev. 1, Westinghouse Hanford Company, Richland, Washington.

Simpson, B. C., 1994, Tank 241-T-111 Characterization Report, WHC-EP-0806, Westinghouse Hanford Company, Richland, Washington.

Sloat, R. J., 1954, TBP Plant Nickel Ferrocyanide Scavenging Flowsheet, HW-30399, General Electric Company, Richland, Washington.

Sloat, R. J., 1955, In-Farm Scavenging Operating Procedure and Control Data, HW-38955, Generai Eiecuric Comîyâny, Richìand, Washington. 
Spore, J. W., S. W. Eisenhawer, M. Ross, and E. Rodriguez, 1994, Double-Shell Tank Bounding Analysis, LA-UR-94-2088, Los Alamos National Laboratory, Los Alamos, New Mexico.

Toffer, H., 1995, Vendor Survey for the Electromagnetic Induction (EMI) Logging Project, (internal memorandum to G. T. Dukelow, January 10), Westinghouse Hanford Company, Richland, Washington.

Toth, J. J., P. J. Heasier, C. C. Willingham, and P. D. Whitney, 1994, Organic Carbon in Hanford Single-Shell Tank Waste, PNL-9434, Pacific Northwest Laboratory, Richland, Washington.

Toth, J. J., P. G. Heasler, M. E. Lerchen, J. G. Hill, and P. D. Whitney, 1995, Analysis of Organic Carbon and Moisture in Hanford Single-Shell Tank Waste, Pacific Northwest Laboratory, Richland, Washington.

Valenzuela, B. D., and L. Jensen, 1994, Tank Characterization Report for Single-Shell Tank 241-T-107, WHC-SD-WM-ER-382, Rev. 0, Westinghouse Hanford Company, Richland, Washington.

Watson, W. T., 1993, Proof of Principle Report for In-Tank Moisture Monitoring Using an Active Neutron Probe, WHC-EP-0695, Westinghouse Hanford Company, Richland, Washington.

Webb, A. B., D. M. Camaioni, J. M. Grigsby, P. G. Heasler, B. Malinovic, M. G. Plys, J. L. Stewart, J. J. Toth, and D. A. Turner, 1995, Preliminary Safety Criteria for Organic Watch List Tanks at the Hanford Site, WHC-SD-WM-SARR-033, Rev. 0, Westinghouse Hanford Company, Richland, Washington.

WHC, 1992, Standard Hydrogen Monitoring System Design Description, WHC-SD-WM-SDD-001, Rev. 0, Westinghouse Hanford Company, Richland, Washington.

WHC, 1994, Operating Specifications for Watch List Tanks, OSD-T-151-00030, Rev. B-2, Westinghouse Hanford Company, Richland, Washington.

WHC, 1995, 45 Lay Safety Screen Results for Tank 241-C-108, Augers 94-012, 94-014, and 94-015, WHC-SD-WM-DP-082, Rev. 0, Westinghouse Hanford Company, Richland, Washington.

Wilkins, N. E., 1995, Results of Gas Monitoring of Double-Shell Flammable Gas Watch List Tanks, WHC-SD-WM-TI-682, Rev. 0, Westinghouse Hanford Company, Richland, Washington. 
Wood, S. A., 1993, Gas Space Analysis of Tank C-109, WHC-SD-WM-ER-183, Rev. 0, Westinghouse Hanford Company, Richland, Washington. 
This page intentionally left blank. 
APPENDIX A

TANKS CURRENTLY ON THE WATCAI LIST

A-1 
This page intentionally left blank. 
APPENDIX A

TANKS CURRENTLY ON THE WATCH LIST

Table A-1. Tanks Currently on the Watch List.

\begin{tabular}{|c|c|c|c|c|c|}
\hline $\begin{array}{l}\text { Tank } \\
\text { No. }\end{array}$ & Category & $\begin{array}{l}\text { Tank } \\
\text { No. }\end{array}$ & Category & $\begin{array}{l}\text { Tank } \\
\text { No. }\end{array}$ & Category \\
\hline A-101 & $\begin{array}{c}\text { Hydrogen } \\
\text { Organics }\end{array}$ & S-102 & $\begin{array}{c}\text { Hydrogen } \\
\text { Organics }\end{array}$ & U-103 & $\begin{array}{c}\text { Hydrogen } \\
\text { Organics }\end{array}$ \\
\hline AX-101 & Hydrogen & $S-111$ & Hydrogen & U-105 & Hydrogen \\
\hline AX-102 & Organics & & Organics & & Organics \\
\hline$A X-103$ & Hydrogen & s-112 & Hydrogen & $\mathrm{U}-106$ & Organics \\
\hline B-103 & Organics & SX-101 & Hydrogen & U-107 & Organics \\
\hline BY-103 & Ferrocyanide & SX-102 & Hydrogen & & Hydrogen \\
\hline BY-104 & Ferrocyanide & SX-103 & Hydrogen & U-108 & Hydrogen \\
\hline BY-105 & Ferrocyanide & & Organics & U-109 & Hydrogen \\
\hline BY -106 & Ferrocyanide & SX-104 & Hydrogen & U-111 & Hydrogen \\
\hline BY-107 & Ferrocyanide & SX-105 & Hydrogen & U-203 & Organics \\
\hline BY -108 & Ferrocyanide & SX-106 & Hydrogen & U-204 & Organics \\
\hline BY -110 & Ferrocyanide & & Organics & $A N-113$ & Hydrogen \\
\hline BY -111 & Ferrocyaride & SX-109 & Hydrogen & AN-104 & Hydrogen \\
\hline BY -112 & Ferrocyanide & $\mathrm{T}-107$ & Ferrocyanide & AN-105 & Hydrogen \\
\hline$C-102$ & Organics & $T-110$ & Hydrogen & AW-101 & Hydrogen \\
\hline C-1.03 & Organics & $T-111$ & Organics & SY-101 & Hydrogen \\
\hline$C-106$ & High Heat & $\mathrm{TX}-105$ & Organics & SY-103 & Hydrogen \\
\hline C-108 & Ferrocyanide & $\mathrm{TX}-118$ & Ferrocyanide & & \\
\hline C- 109 & Ferrocyanide & & Organics & & \\
\hline C- -111 & Ferrocyanide & TY-101 & Ferrocyanide & & \\
\hline C-112 & Ferrocyanide & TY-103 & Ferrocyanide & & \\
\hline & & TY-104 & $\begin{array}{c}\text { Ferrocyanide } \\
\text { Organics }\end{array}$ & & \\
\hline
\end{tabular}


This page intentionally left blank. 
APPENDIX B

HOMOGENEITY IN THE HEADSPACE

B-1 
This page intentionally left blank. 


\section{APPENDIX B}

\section{HOMOGENEITY IN THE HEADSPACE}

Concentrations of constituents in the vapor are not expected to fluctuate greatly over time, and headspaces are well-mixed (even in passively ventilated tanks). Provided samples are collected at least several centimeters away from the waste surface or tank walls, and a meter away from the bottom of an obvious source of fresh air (e.g., an open riser), the sample should be representative of the headspace vapor mixture. Several sources of information from the Ferrocyanide, Flammable Gas, Organic, and Vapor Safety Programs support this conclusion.

\section{B.1 HUADSPACE MODELING}

Modeling indicates that the headspace dynamics of passively ventilated waste tanks are dominated by thermally induced convection currents ${ }^{1}$ (Wood 1993). In general, radioactive decay in tank waste results in waste surface temperatures that are higher than the temperatures of the tank dome and ground above the dome. Air warmed by contact with the waste surface rises as cooler, denser air from near the dome displaces it. This convection mixes the gases and vapors both vertically and horizontally within the headspace, limiting concentration gradients within the convective zone. In the regions very near the waste, dome, or walls of the tank (boundary zones), concentration gradients are limited by molecular diffusion.

The effect of thermally induced convection on gas concentrations in a tank with a' localized gas source was also examined (Claybrook and Wood 1994). A three-dimensional model was developed to simulate the evaporation of an organic liquid from the waste surface while a small stream of air flowed through the headspace. Three sensitivity calculations were made in which the difference between the waste surface temperature and top of the headspace was assumed to be $5^{\circ} \mathrm{C}$ and $1{ }^{\circ} \mathrm{C}$ higher, and $5^{\circ} \mathrm{C}$ cooler. When the waste surface is warmer than the dome, vertical mixing prevents any substantial vapor concentration gradients from forming. When the waste surface temperature was $1{ }^{\circ} \mathrm{C}$ higher than the dome temperature (and no thermally induced convection existed), vapor concentration differences between selected locations were relatively small.

Modeling of the 241-C-107, -108 , and -109 cascade, which included the effects of interconnection, revealed that the maximum concentration differences within tank 241-C-109 would be less than 0.001\% (Wood 1993). Claybrook and Wood (1994) examined potential vertical concentration gradients as a result of density differences. Using a very conservative

'This does not include tanks subject to periodic gas releases. 
assumption of no convection, molecular diffusion limited the hydrogen concentration variation from the waste surface to the top of the dome (about $10 \mathrm{~m}$ ) to about $0.001 \%$. Under the same conditions, the concentration variation in the headspace of a very heavy vapor (tributyl phosphate) was estimated to be only about $0.8 \%$.

\section{B.2 SAMPLING}

Sampling has also indicated that the headspace is well mixed. Gas and vapor samples collected from three elevations of the headspace of tank 241-C-103 suggest no vertical stratification exists (Huckaby and Story 1994). Analyses of several gases and vapors, including ammonia, water vapor, hydrogen, and semivolatile alkanes measured $0.79,2.92$, and $5.05 \mathrm{~m}$ above the waste surface, indicated no significant concentration differences at the three elevations.

To confirm the model of headspace homogeneity, additional vertical and horizontal profiling will be conducted on selected tanks over time. Samples will be collected from five elevations distributed equally between the bottom of the riser opening and the surface of the waste. The evaluation of headspace mixing will be based upon the distribution of a limited number of screening analytes (i.e., hydrogen, methane, ammonia, carbon monoxide, and nitrous oxide. Some tanks will be simultaneously sampled through a secondary riser offering the maximum horizontal displacement from the primary riser. This will provide data for resolution of horizontal spacial variability. Some tank headspaces will be re-sampled at different isme intervals to determine if the composition varies over time.

This body of work would entail some 30 special vapor sampling study evaluations on about nine tanks in FY 1996. Examples of study tank candidates (rationale in parenthesis) are tanks 241-C-103 (complex organic matrix), 241-BY-107, 241-BY-108 (strong organic signature over interim-stabilized saltcake), 241-BY-104 (vapor signature over low volume of residual waste), 241-U-106, 241-U-111, 241-U-112 (strong ammonia vapor matrix), 241-C-101, and 241-C-102 (headspace shared with 241-C-103 and cross-communication issues between cascade tanks). 
APPENDIX C

DETECTION OF A SEPARABLE ORGANIC PHASE 
This page intentionally left blank. 


\section{APPENDIX C}

\section{C.0 DETECTION OF A SEPARABLE ORGANIC PHASE}

Examination of the sampling and modeling performed to date supports the hypothesis that the concentration of semivolatile substances in headspace air is predictable on the basis of pool temperature, surface area and composition. A summary of the modeling and sampling information is presented in this Appendix.

\section{C.1 MODELING OF THE HEADSPACE}

Computational models have been developed to examine the issue of headspace homogeneity. These include the estimation of waste tank breathing rates (Crippen 1993), the calculation of equilibrium vapor concentrations above the semivolatile organic liquid in tank 241-C-103, the evaporation rate of organic liquid in tank 241-C-103, and the distribution of gases and vapors within a tank headspace (Claybrook and Wood 1994). Results of these studies are consistent with the results of headspace sampling (Table C-1).

Claybrook and Wood (1994) modeled the evaporation of semivolatile organics in tank 241-C-103. The model indicates that even when the vapor concentrations are reduced to $10 \%$ of their equilibrium values, evaporation in a headspace mixed by thermally induced convection re-establishes near-equilibrium vapor concentrations in about 4 to 5 days. During the re-establishment of vapor-liquid equilibrium, the headspace still contains an essentially homogeneous distribution of the organic vapors.

A similar calculation was performed in which an inverted thermal profile was used to eliminate thermal convection (the dome was $10^{\circ} \mathrm{C}$ higher than the liquid surface). Mixing was completely diffusion controlled, and vapor-liquid equilibrium was re-established within 10 to 15 days. In this latter calculation, it was also found that concentrations at different points within the headspace were virtually the same after 4 to 5 days.

Postma et al. (1994b) also modeled evaporation rates in tank 241-C-103. The estimated time for a typical semivolatile constituent to reach $90 \%$ of its equilibrium headspace concentration was approximately ?.5 hours. When compared to the tank breathing rates of 0.5 to $5 \%$ of the headspace volume per day, the evaporation rate of semivolatile organic liquid is fast, using either of the models presented in Claybrook and Wood (1994) or Postma et al. (1994b). 


\section{C.2 SAMPLING RESULTS}

A comparison of the liquid samples collected in December 1993 and vapor samples collected in December 1993 and May 1994 from tank 241-C-103 is presented in Table C-1. The three dominant semivolatile normal paraffin hydrocarbons (NPHs) found in tank 241-C-103 are $\mathrm{n}$-undecane, $\mathrm{n}$-dodecane, and $\mathrm{n}$-tridecane (column 1). The concentrations measured in the tank headspace (Huckaby and Story 1994) are shown in the second column of Table C-1. The third column gives the concentration measured above an aliquot of the tank's organic liquid when it was heated to $40^{\circ} \mathrm{C}$ (Pool and Bean 1994), the estimated temperature of the waste surface.

Table C-1. Comparison of Tank 241-C-103 Organic Solvent and Vapor Data.

\begin{tabular}{|l|c|c|c|}
\hline \multicolumn{1}{|c|}{ Compound } & $\begin{array}{c}\text { Tank Headspace } \\
\text { Vapor Sample } \\
\left(\mathrm{mg} / \mathrm{m}^{3}\right)\end{array}$ & $\begin{array}{c}\text { Headspace of } \\
\text { Liquid Sample at } \\
40^{\circ} \mathrm{C}\left(\mathrm{mg} / \mathrm{m}^{3}\right)\end{array}$ & $\begin{array}{c}\text { Calculated at } \\
40^{\circ} \mathrm{C} \\
\left(\mathrm{mg} / \mathrm{m}^{3}\right)\end{array}$ \\
\hline n-undecane & 22.3 & 60 & $\mathrm{NA}^{*}$ \\
\hline n-dodecane & 268 & 320 & 196 \\
\hline n-tridecane & 350 & 460 & 271 \\
\hline
\end{tabular}

* NA = Not applicable. Calculations are based on liquid sample analyses, and $\mathrm{n}$-undecane was not detected in the liquid sample.

The concentrations found in the tank headspace (column 2) and above the liquid sample (column 3) are consistent with the assumption of near equilibrium in the headspace. This agreement indicates that organic vapors in a passively ventilated waste tank should be in equilibrium with the organic solvent pool.

Also shown in Table C-1 (column 4) are NPH concentrations calculated using Raoult's Law and Antoine equation vapor pressures (Claybrook and Wood 1994). At $40^{\circ} \mathrm{C}$ (the estimated temperature of the waste surface in tank 241-C-103), the calculated vapor concentrations are only about 20 to $30 \%$ lower than the observed concentrations given in column 2 . 


\section{APPENDIX D}

PRELIMINARY NEAR-SURFACE CALCULATIONS 
This page intentionally left blank. 
APPENDIX D

\section{PRELIMINARY NEAR-SURFACE CALCULATIONS}

Credible initiators deposit energy on the waste surface (Bajwa 1994, Scaief 1991), and it is important to define what constitutes "near surface." There are two important questions that need to be answered to determine the depth an initiator could penetrate: (1) how far would a hot object penetrate if it fell on the waste; and (2) how far would the heat be conducted once an initiator is in contact with the waste? The first question can be answered by examining accident scenarios to determine the size and weight of potential initiators, and the likely distance an initiator would fall. A safety analysis examining potential initiator scenarios will be completed in June 1995. However, it is possible to make some qualitative judgements on how far a falling initiator would penetrate.

Larger objects with the potential to fall into the waste during operations are tethered to reduce the risk of dropping them (e.g., lights, video equipment, still camera). Other potential initiators that have been postulated, such as hot slag from welding, sparks from grinding, or burning gasoline, do not have a large mass and would probably not penetrate very far. Drier waste is hard (most saltcake waste requires rotary-mode core sampling because the waste cannot be penetrated by the push-mode sampler at the 1000-psi pressure limit) and objects would probably not penetrate very deeply if dropped on the waste. As the moisture content of the waste increases, the waste softens and dropped objects will penetrate farther; but wet waste does not pose a propagation hazard (see Section 2.0). Sludge waste may have some shallow surface cracks as a result of drying and consolidation; however, sludges retain considerable water (see Section 3.5.4) and therefore do not pose a propagation hazard.

If a high temperature were instantaneously supplied to the surface of the waste, the temperature at any point can be calculated if some parameters are known. Transient one-dimensional heat conduction in a semi-infinite solid is given by

$$
\frac{\partial^{2} T}{\partial x^{2}}=\frac{1}{\alpha} \frac{\partial T}{\partial t}
$$

Some simplifying assumptions will be made to solve this equation. The effects of phase changes as a result of waste heating (the nitrate/nitrite salts would melt around $250^{\circ} \mathrm{C}$ ) will be ignored. The boundaries are assumed to be, $T(x, 0)=T_{0}, T(\infty, t)=T_{0}$, and $T(0, t)=T_{a}$; and the solution (Kreith and Black 1980) to Equation D-1 is 


$$
\frac{T(x, t)-T_{s}}{T_{0}-T_{s}}=\operatorname{erf}\left(\frac{x}{2 \sqrt{\alpha t}}\right)
$$

where $\mathrm{T}_{0}=$ ambient temperature

$T_{1}=$ temperature of hot surface

$\alpha=$ thermal diffusivity

$x=$ distance

$\mathrm{t}=$ time

err $=$ Gauss error function.

The temperature of interest, $\mathrm{T}(\mathrm{x}, \mathrm{t})$, is $200^{\circ} \mathrm{C}$, the temperature ignition criteria for condensed-phase propagating reactions (Webb et al. 1995). The ambient waste temperature, $\mathrm{T}_{0}$, is assumed to be $30^{\circ} \mathrm{C}$. A reasonable diffusivity for Hanford Site waste is $10^{-6} \mathrm{~m}^{2} / \mathrm{s}$, which is about the value calculated for waste sludge simulants (Jeppson and Wong 1993). For comparison, the diffusivity of carbon steel, a moist clay (containing $49 \mathrm{wt} \%$ water), and wood are about $10^{-5}, 10^{-6}$, and $10^{-7} \mathrm{~m}^{2} / \mathrm{s}$, respectively (Kreith and Black 1980). A plot of depth as a function of time for different temperatures is shown in Figure D-1.

Figure D-1. Depth of Waste Reaching $200^{\circ} \mathrm{C}$ as a Function of time for Various Initiator Temperatures

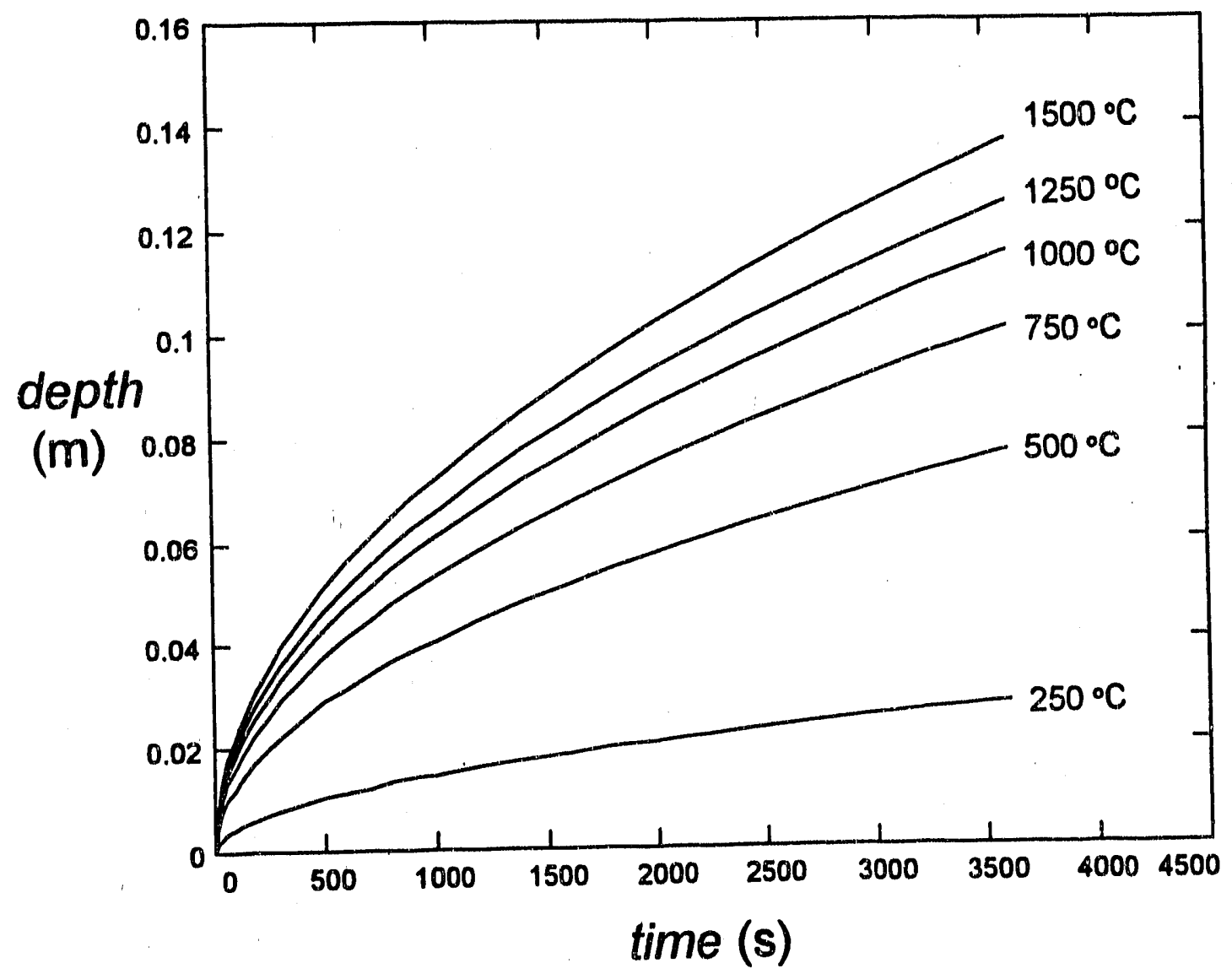


Typical initiators last for only seconds or minutes, and from Figure D-1 it can be concluded that the heat would be conducted to a depth of only a few centimeters. However, to adjust for the penetration of a falling initiator and to add conservatism to the calculation, a high initiator temperature $\left(1500^{\circ} \mathrm{C}\right.$, about the temperature of molten iron) and a long duration (one hour) will be used to determine "near surface." For an initiator at $1500^{\circ} \mathrm{C}$, the waste depth of interest is 2 to $14 \mathrm{~cm}$. This estimate of "near surface" will be refined once the safety analysis is completed in June 1995. 
This page intentionally left blank.

$D=6$ 


\section{DISTRIBUTION}

Number of copies

\section{QEFSITE}

7

U.S. Department of Energy

Trevion II

12800 Miádlebrook Road

Germantown, MD 20874

James V. Antizzo, EM-36

Charles O'Dell (5), EM-36

Shirley Campbell-Grizzel, EH-15

1

Charles S. Abrams

1987 Virginia

Idaho Falls, ID 83404

1

David O. Campbell

102 Windham Road

Oak Ridge, TN 37830

1

Fred N. Carlson

6965 North 5th West

Idaho Falls, ID 83401

1

Billy C. Hudson

202 Northridge Court

Lindsborg, KA 67456

1

Brookhaven National Laboratory

Upton, NY 11973

Kamal K. Bandyopadhyay

1

Desien Science, Inc.

163 Witherow Road

Sewickley, PA 15143

Gary Powers 


\section{DISTRLBUTION}

Number of copies

QFESITE (Continued)

1

Eauske and Associates. Inc.

16 W070 W. 83rd St.

Burr Ridge, II 60521

Hans K. Fauske

2

Q \& $P$ Consulting. Inc.

3640 Ballard Road

Dallas, OR 97338

J. Michael Grigsby

Arlin K, Postma

3

Los Alames National Laberatory.

P.O. Box 1663

Los Alamos, NM 87545

Steve F. Agnew

Steve W. Eisenhawer

Thomas E. Larson

1

MIT/Department of Nuclear Engineering

77 Massachusetts Ave.

Room 24-102

Cambridge, MA 02139

Mujid S. Kazimi

1 Nuclear Consulting Services. Inc.

P.O. Box 29151

Columbus, $\mathrm{OH} \quad 43229-0151$

J. Louis Kovach 


\section{DISTRIBUTION}

Number of copies

QEESTTE (Continued)

1

Qak Ridge National Laboratory

Emory D. Collins

P.O. Box 2008

7930, MS-6385

Oak Ridge, TN 37831-6385

1

Charles W. Forsberg

P.O. Box 2008

MS-6495

Oak Ridge, TN 37831-6495

1

Thomas S. Kress

P.O. Box 2009

9108, MS-8088

Oak Ridge, TN $37831-8088$

1

Rice University

5211 Paisley

Houston, TX 77096

Andrew S. Veletsos

2

Sandia National Laboratories

P.O. Box 5800

Albuquerque, NM 87185

Dana A. Powers, MS-0744

Scott E. Slezak, MS-0741

3

Science Applications International Corporation 20300 Century Blvd, Suite 200-B

Germantown, MD 20874

Ray S. Daniels (3) 


\section{DISTRIBUU'TON}

Number of copjes

OEESITE (Continued)

1

State of Washington - Department of Ecology

Michael T. Gordon

P. O. Box 47600

Olympia, WA 98504-7600

1

Alex Stone

1315 W. 4th Avenue

Kennewick, WA 99336

\section{QNSLTE}

9

U.S. Department of Energy, Richland Operations Office

R. F. Christensen (2)

L. Erickson (2)

R. E. Gerion (2)

Public Reading Room

H2.-53

RL Docket File (2)

Racific Northwest Laboratory

J. L. Huckaby

B. M. Johnson

G. F. Schiefelbein

C. S. Simmons

K6-77

D. M. Strachan

K9-78

Hanford Technical Library

P8-55

Westinghouse Hanford Company

H. Babad

R. J. Cash

S7-15

M. D. Crippen

D. R. Dickinson

G. T. Dukelow

S. J. Eberlein

R2-12

L. F. Ermold

S7-84

D. W. Hamilton

S7-15 


\section{DISTRIBUTION}

ONSITE (Continued)

G. D. Johnson

S7.15

T. J. Kelley

S7-30

N. W. Kirch

R2-11

J. E. Meacham

S7-1.5

J. W. Osborne

S7-15

M. A. Payne

S7-14

D. A. Sherwood

S7-15

D. A. Turner

S7-15

A. M. Umek

S7-81

Central Files

L8-04

EDMC

H6-08

OSTI (2)

L8-07

TFIC

R1-20 

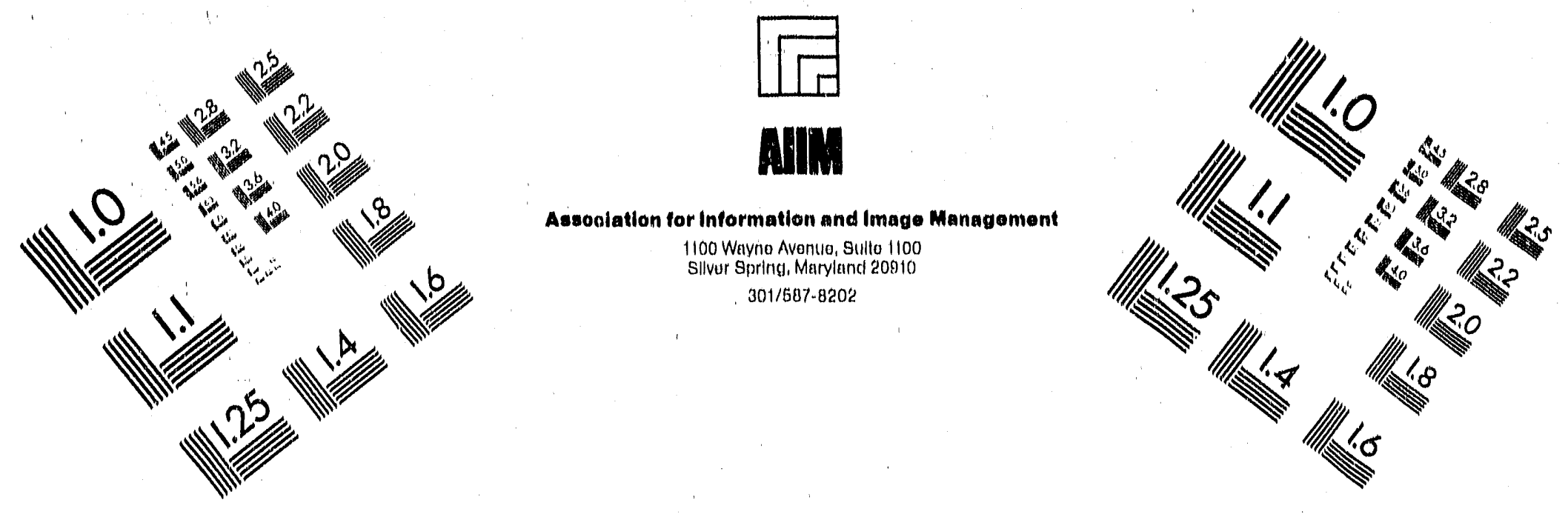

\section{Centimeter}

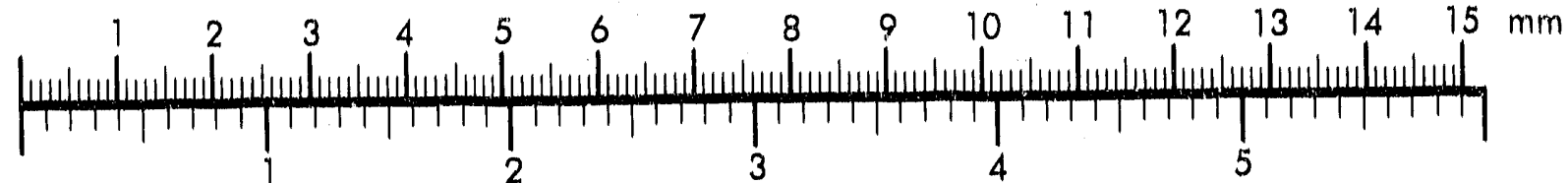

Inches
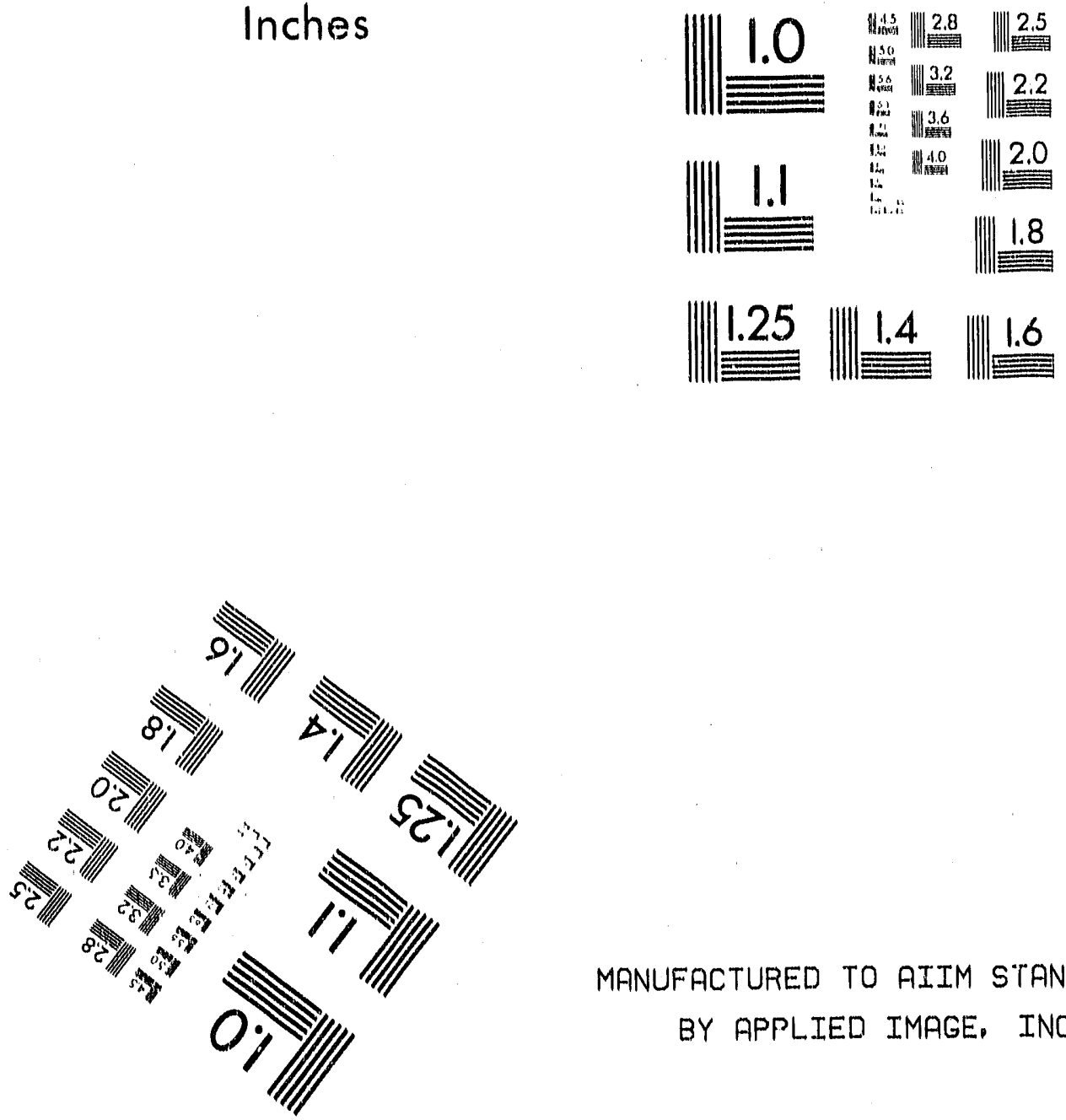

MANUFACTURED TO AIIM STANDARDS

BY APPLIED IMAGE, INC.

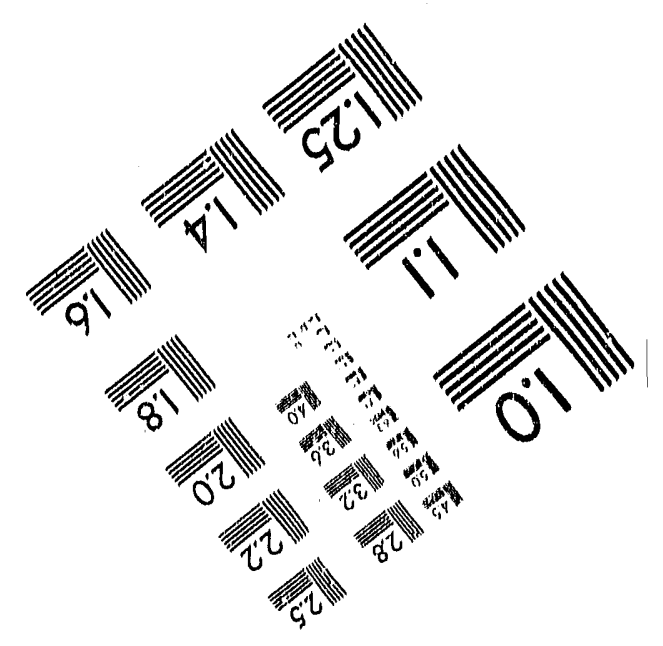




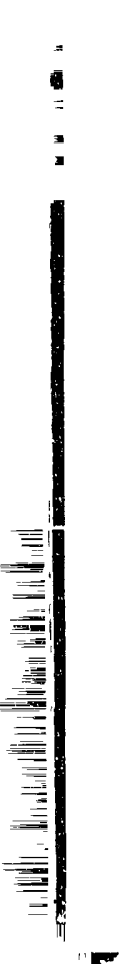

1 

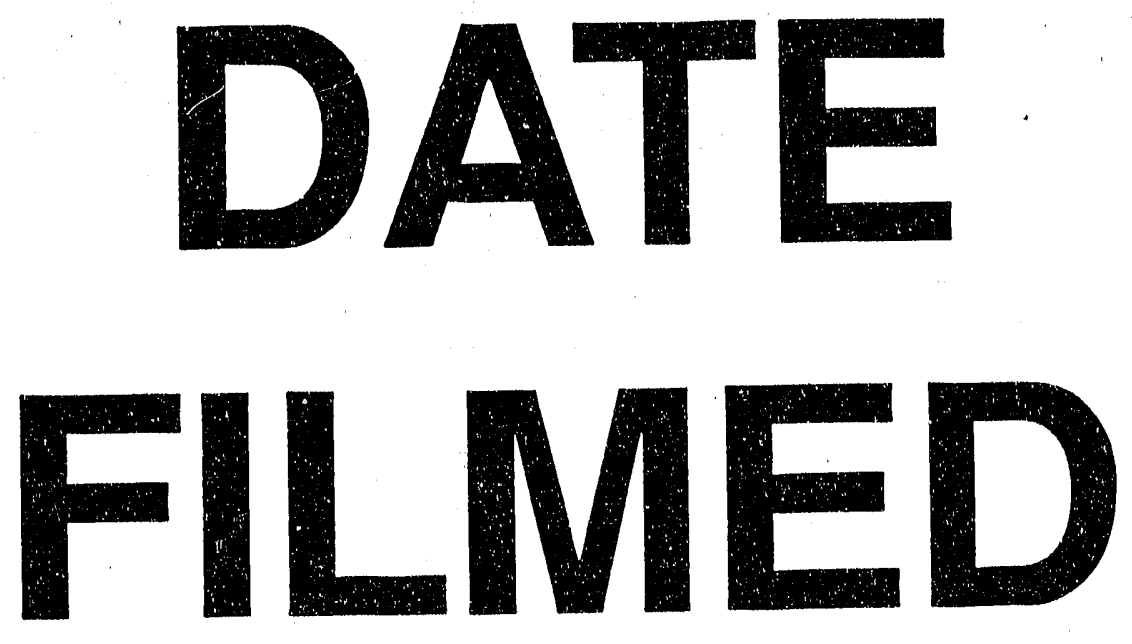

$6 / 22 / 95$
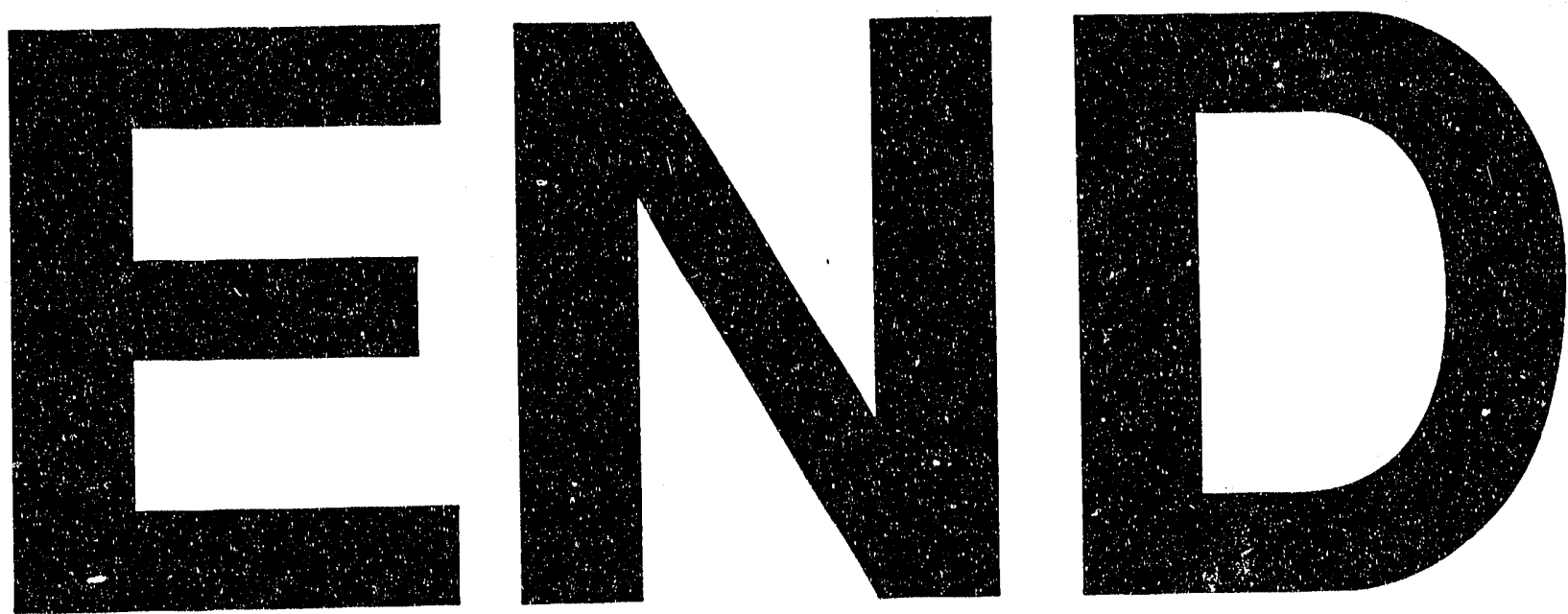

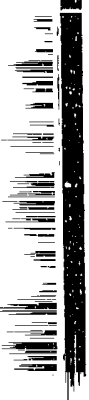

